\title{
Türkiye'de Arşivcilik Alanındaki Araştırma Sorunları: Arşiv Dünyası Dergisinde Yayınlanan Makalelerin İçerik Analizi*
}

\section{Research Issues in the Archival Field in Turkey: Content Analysis of the Articles Published in The Journal of Archive World}

\author{
Ceyhan Güler ${ }^{1}$ (), İshak Keskin² ${ }^{2}$
}

*Bu makale, 04-07 Ağustos 2018 tarihlerinde Komrat Devlet Üniversitesinde (Komrat, Gagauz Yeri, Moldova) düzenlenen " $2^{\text {nd }}$ International Symposium on Humanities and Social Sciences" adlı sempozyumda "Türkiye'de Arșivciliğin Araștırma Sorunları: Arșiv Dünyası Dergisinde Yayınlanan Makalelerin İçerik Analizi" bașlığı ile sunulan bildiri metninin genişletilmiş ve gözden geçirilmiş halidir.

${ }^{1}$ Sorumlu yazar/Corresponding author: Ceyhan Güler (Araş. Gör. Dr.), İstanbul Üniversitesi, Edebiyat Fakültesi, Bilgi ve Belge Yönetimi Bölümü, İstanbul, Türkiye E-posta: ceyhan.guler@istanbul.edu.tr ORCID: 0000-0003-0099-8168

${ }^{2}$ İshak Keskin (Prof. Dr.),

İstanbul Üniversitesi, Edebiyat Fakültesi, Bilgi ve Belge Yönetimi Bölümü, İstanbul, Türkiye E-posta: ishak.keskin@istanbul.edu.tr ORCID: 0000-0003-1611-1330

Başvuru/Submitted: 02.08.2019

Revizyon Talebi/Revision Requested: 01.10.2019 Son Revizyon/Last Revision Received: 14.10.2019 Kabul/Accepted: 10.11.2019

Atıf/Citation: Soyadi, A. (2020). Türkiye'de arșivcilik alanındaki araștırma sorunları: Arșiv Dünyası Dergisinde yayınlanan makalelerin içerik inalizi. Bilgi ve Belge Araştırmalart Dergisi, 13, 1-31. https://10.26650/bba.2020.13.01
ÖZ

Arşiv Dünyası, ilk sayısı 1999 yılında çıkan, 2008 yılından itibaren ulusal hakemli dergi statüsünde yayın hayatına devam eden ve bu süre boyunca toplam 17 sayı (1999-2014) yayımlanmış olan bir dergidir. Arșiv Dünyası dergisi, 2017 yll itibariyle elektronik ortamda ve ulusal hakemli statüsünde yayımlanmaya başlamıştır. Bu araştırmada, Arşiv Dünyası dergisinde 1999-2014 yılları arasında yayımlanan 17 sayıdaki makalelerin içerik analizi yapılmıştır. 2018 yılı itibariyle başlayan yeni dönem, çalışmanın kapsamı dışında tutulmuştur. Analizde; makalelerin yayın türü, sayfa sayıları, makale konuları, makalelerde kullanılan yöntem, veri toplama tekniği, makalelerdeki Türkçe-İngilizce öz verilmesi, dipnot-kaynakça bilgisi ve yazarların hangi kurumlardan katkıda bulundukları çerçevesinde içerik değerlendirmesi yapılmaktadır. Dergide yayınlanan hakemsiz makalelerin oran $\% 32,99$, hakemli makalelerin oranı ise $\% 24,49$ 'dur. Makalelerde ele alınan konuların \%47,93'ü arşivcilik bilimiyle ilgili, \%52,07'si ise arşivcilikle ilgili olmayan ağırlıklı olarak tarih biliminin çalışma sahalarıla ilgili konulardan meydana gelmektedir. Betimleme $(\% 33,19)$ ve içerik analizi $(\% 27,73)$ yöntemleri makalelerde ağırlıklı olarak kullanılan yöntemlerdir. Kullanılan veri toplama tekniği ise genellikle içerik analizidir $(\% 29,83)$. Bunun yanı sıra (daha önce toplanan verileri kullanma, gözlem, tarihsel kaynak analizi ve yüksek sesle düşünme) $(\% 24,79)$ gibi veri toplama tekniklerinin de kullanıldığı belirlenmiștir. Anahtar kelimeler: Arşivcilik literatürü, Arşiv Dünyası dergisi, bibliyometri, içerik analizi

\section{ABSTRACT}

Arşiv Dünyası (AD) has been published since 1999. AaD was published a total of 17 times between 1999 and 2014. AD became a refereed journal in 2008. As a national refereed journal, the journal titled $\mathrm{AD}$ has been published electronically since 2017 . In this research, the contents of articles in 17 journals published between 1999-2014 have been analiyzed. The new period starting in 2018 is excluded from the scope of the research. In the analysis, content evaluation is carried out within the framework of the type of the articles, page number, article topics, method used, data collection technique, Turkish/English abstract, annotation/bibliography and information about to which institutions the authors contribute. In this research, the rate of non-refereed articles is $32.99 \%$, while the rate of refereed articles is $24.49 \% .52 .07 \%$ of the subjects of the articles published in $\mathrm{AD}$ are related to the history of science, while $47.93 \%$ of the relevant articles are related to archival and archival issues. If we look through the methods used in this study, descriptive methods (33.19\%) and content analysis (27.73) come to the forefront. As the data collection technique, content analysis (29.83\%) and various other techniques $(24.79 \%)$ such as previously collected data, observation, historical resource analysis, and thinking aloud were used.

Keywords: Archival literature, journal of archive world, bibliometrics, content analysis 


\section{EXTENDED ABSTRACT}

Arşiv Dünyası (AD) has been published since 1999. AD was published a total of 17 times between 1999 and 2014. AD became a refereed journal in 2008. As a national refereed journal, the journal titled AD has been published electronically since 2017. In this research, the contents of articles in 17 journals published between 1999-2014 have been analyzed. The new period starting in 2018 is excluded from the scope of the research. In the analysis, content evaluation is carried out within the framework of the type of the articles, page number, article topics, method used, data collection technique, Turkish / English abstract, annotation / bibliography and information about to which institutions the authors contribute. In this research, the rate of non-refereed articles is $32.99 \%$, while the rate of refereed articles is $24.49 \% .1189$ pages were published in the journal between 1999-2014. 636 (53.49\%) of these were published before it became refereed, $553(46.50 \%)$ after. $52.07 \%$ of the subjects of the articles published in $\mathrm{AD}$ are related to the history of science, while $47.93 \%$ of the relevant articles are related to archival and archival issues (the subjects matched with archival journal literature from several of the leading journals in the field, such as the American Archivist, Archivaria, Archives and Manuscripts, Journal of the Society of Archivists and Archival Science). If we look through the methods used in this study, descriptive methods (33.19\%) and content analysis $(27.73 \%)$ come to the forefront. As the data collection technique, content analysis $(29.83 \%)$ and various other techniques $(24.79 \%)$ such as previously collected data, observation, historical resource analysis, and thinking aloud were used. The percentage of articles having abstracts in Turkish and English is $11.64 \%$, while the percentage of articles not having abstracts in Turkish and English is $85.71 \%$. The percentage of articles having only abstracts in Turkish is $2.65 \%$. The rate of articles not having annotations and bibliographies is $35.11 \%$. The rate of articles having only annotations is $31.91 \%$, while $17.08 \%$ of the relevant articles have only bibliographies. The rate of articles having both annotations and bibliographies is $15.96 \%$. Finally, the articles were written by 108 different authors representing 33 institutions both domestic and abroad. The overwhelming majority of the articles were written by a single author. Although researchers affiliated with the departments of information and records management have authored the minority of the articles, they have become far better represented in archival literature. The problems facing $\mathrm{AD}$ are also discussed along with some recommendations. Firstly, it is clear that a journal with strong publication principles will increase its reputation in the professional community and scientific publishing field, and this will increase the number of publication demands. Secondly, the editors who were clearly responsible for the implementation of these principles could not properly fulfil their obligations. This seems to cause problems in the journal's publishing life. Thirdly, there is no doubt that if the journal is indexed in national and international directories, by eliminating the negativities identified in the study, the journal will be given more importance and demand in the professional community. Finally, as the world of scholarly communication changes, professional discourse should be able to change with it. 


\section{GİRIŞ}

Arşiv Dünyası dergisi, Devlet Arşivleri Genel Müdürlüğü (şimdi Devlet Arşivleri Başkanlığı) çalışanlarınca 1998 yılında kurulan Tüm Arşivciler Derneğinin (kuruluş 1998; 2006 yılı itibariyle Türk Arşivciler Derneği) 1999 yılından beri yılda iki sayı (İlkbahar ve Kış) olmak üzere yayınlamaya çalıştığı bir dergidir. Tüm Arşivciler Derneğinin yayınladığı Bülten'in devamı olan Arşiv Dünyası Dergisi ${ }^{1} 2008$ yılından itibaren hakemli bir dergi olarak yayın hayatına devam etmektedir. Yılda iki defa yayımlanma amacını taşımasına rağmen düzenli yayımlanmayan derginin, 2014 yılına kadar toplam 17 sayısı yayımlanabilmiştir. Derginin 14.-15. ve 16.-17. sayıları ise birleşik sayılar şeklinde yayımlanmıştır. Böylelikle derginin toplam 15 cilt halinde sayı basımı gerçekleşmiştir. Söz konusu dergi, 2017 yılı itibariyle ULAKBİM DergiPark' da elektronik ve ulusal hakemli statüsünde yayınlanmaya başlamıştır. 2017 yılı içerisinde yayınlanan 18.-19. sayılar -son dört sayıda olduğu gibi- yine birleştirilerek yayınlanmıştır. 2018 yılının 20. ve 21. sayıları ile 2019 yılının ilk sayısı (22. sayı) ise ayrı sayılar halinde okurları ile buluşmuştur. 2017-2019 yılları arasında yayınlanan sayılardan (18.-22. sayılar) dergi yayın politikasında değişikliğe gidildiği anlaşılmaktadır. Söz konusu dergiye ait ve 2017-2019 yılları arasında yayınlanan sayılardan, -olması gerektiği şekilde- bilgi ve belge yönetimi alanına özel bir yayın politikasının belirlendiği açıç̧a görülmektedir.

"Arşivcilik mesleğini geniş kitlelere tanıtabilmek, anlatabilmek ve sevdirebilmek maksadıyla mesleki konuları ihtiva eden bir yayın organı” (Yavuz, 1999, s. 1) vasfını taşıyan Arşiv Dünyası dergisinde, (alfabetik olarak) anma toplantısı, basın bildirisi, diğer, editör yazısı, faaliyet, gezi, haberler, hakemli makaleler, hakemsiz makaleler, iktibas, kitap tanıtımı, konferans, mülakat (görüşme), sempozyum programı, serbest yazı, sergi, televizyon programı, yeni yayınlar, yönetim kurulu başkanı yazısı olmak üzere toplam 19 yayın türünde 294 yazıya yer verilmiştir. Arşiv Dünyası dergisi, Türkiye arşivciliğinin gelişimi için (arşivcilik mesleğinin tanıtılması, arşiv kaynakları hakkında bilgilendirmelerin yapılması ve üniversitelerdeki Bilgi ve Belge Yönetimi Bölümlerindeki araştırmacıların klasik ve modern arşivcilik üzerine hazırladıkları çalışmalarını yayınlamaları) önemli bir yayın organıdır. Söz konusu araştırma, böyle önemli bir yayının geçmişteki yayın politikasının gözden geçirilmesi, yayınlanmış sayılarına ilişkin içerik analizinin yapılması, böylelikle derginin gelecekteki yayın politikasına yön verilmesi bakımından önemlidir.

1 Arşiv Dünyası, editör tarafından kaleme alınan 3. sayısında bülten olarak nitelendirilmektedir. Aynı yayının 4. sayısında, editör ifadesinde yayın için ne bülten ne de dergi olarak (... bu sayımızda ...) söz edilmediği dikkat çekmektedir. Derginin 5. sayısında editör tarafından kaleme alınan sunuş yazısında ise, yayından “dergi” olarak söz edilmektedir. Şu halde, ilgili yayının 5. sayıdan itibaren dergi olarak kabul edilmesi yerinde olur. 
İçerik analizi ${ }^{2}$ çerçevesinde ele alınan yazılar, hakemli ve hakemli olmayan makalelerden oluşmaktadır. Araştırmanın verileri, 1999-2014 yılları arasında Arşiv Dünyası dergisinde yayınlanan hakemli ve hakemli olmayan 169 yazıdan oluşmaktadır. Bu araştırmada; yayın türü, sayfa sayıları, makale konuları, makalelerde kullanılan yöntem, veri toplama tekniği, makalelerdeki Türkçe-İngilizce öz bilgisine yer verilmesi durumu, dipnot-kaynakça bilgisi ve yazarların hangi kurumlardan katkıda bulundukları bilgisi olmak üzere toplam 8 başlık altında söz konusu derginin içerik analizi sunulmaktadır. İçerik analizi 169 makale ile (hakemli ve hakemsiz yazıların toplamı) sınırlandırılmıştır. Dergide yayınlanan makaleler, hakemli/ hakemsiz oluşlarına göre iki ayrı şekilde değerlendirilmiştir. Makaleler derginin hakemli olmadığı yıllarda yayınlanmışsa hakemsiz, derginin hakemli olarak yayınlandığı tarihten sonra yayınlanmışsa hakemli olarak varsayılmıştır. Bununla birlikte, dergi için hakemli sürecin başladığı tarihten itibaren bütün makalelerin hakemli olup olmadığı, yani yayınlanan makalelerin hakemli/hakemsiz şeklinde gruplandırılmadığı görülmektedir. Dolayısıyla bu durum, yayınlanan bütün yazıların hakemli olarak değer bulmasını beraberinde getirmektedir. Ancak makalelerin içeriksel bakımdan değerlendirilmesi, bu yazıların bir kısmının hakemli olarak yayınlanamayacağı şeklinde bir düşünceyi canlandırmaktadır.

Bu araştırmanın yapılması nedenlerinden biri, Türkiye' de arşivcilik noktasında ele alınan araştırma konularını kapsayan temel bir konu listesinin olmamasıdır. Türkiye'deki Bilgi ve Belge Yönetimi Bölümlerinde dergilere yönelik yapılan içerik analizli çalışmaları genellikle kütüphane bilimini, kısmen de başka alanlarda yayın yapan dergileri kapsamaktadır. Bu nedenle arşivcilik alanına ilişkin araştırma konu listesinin eksikliği söz konusudur. Temel bir listenin eksikliği, arşivcilikle ilgili yazıların profilini olumsuz etkilemektedir. Bu olumsuzluk, yazı yazan araştırmacının kullandığı yöntem ve veri toplama tekniğindeki problemlerin yanı sıra derginin varlık nedenine zarar verecek ilgisiz konuların dergide yer aldığı şeklinde de yorumlanabilir. Dolayısıyla, temel bir araştırma listesinin eksikliğini ortaya koyup, Türkiye'deki arşivcilik alanındaki yayınlar için bir konu listesi önerisi (Amerika'da hazırlanan tezlerde belirlenen arşivcilik konuları gibi) sunmak bu çalışmanın önemini ortaya koymaktadır. Türkiye'de arşivcilik konularını ihtiva eden bibliyometri çalışmalarının yapılması, arşivcilikle ilgili yayınların içerik analizi açısından değerlendirilmesi önem arz etmektedir.

2 İçerik analizi, herhangi bir metin analizi (geniş anlamda kâğıt üzerinde, ses veya videoda veya başka bir ortamda -format veya medya- tutulan ve iletilen bilgiler olarak yorumlanmıştır) içerik analizinin bir parçası olarak düşünülebilir. Ancak amaçlar için yapılan içerik analizi, metinlerle ilgili yinelenebilir ve geçerli çıkarımlar yapmak için sistematik yöntemler kullanan bir araştırma metodolojisidir. İçerik analizi, tanımlanmış özellikler için bir malzeme gövdesinin incelenmesinde yararlı sonuçlar ortaya koyulmasında etkilidir. Böylelikle araştırmacılar daha sonra, bir metnin ya da metin dizisinin niteliği hakkında sonuçlar elde etmek için verilerini teoriden ya da önceki bilgilerden yararlanarak analiz edebilirler (Harper, 2010, s. 13-14). İçerik analizinin bir diğer tanımı ise C. H. Busha ve S. P. Harter tarafından yapılmıştır: Busha ve Harter, "basılı ve görsel-işitsel materyallerin içerdiği paragraflar, cümleler, temalar, kavramlar ve kelimelerin objektif bir analizini gerçekleştiren işlemdir." şeklinde içerik analizinin tanımını yapmışlardır (Busha ve Harter, 1980, s. 172). 
Ele alınan Arşiv Dünyası dergisi özelinde bibliyometri ve içerik analizinin amacı, derginin analiz ve değerlendirmesini sağlamak ve geçerli sonuçlar elde ederek bilimsel yayın değerini ortaya koymak ve yükseltmektir. Bu amaçlarla, arşiv bilimi literatürü için bibliyometri ve içerik analizinden beklenen faydalar şu şekilde sıralanabilir:

1) Derginin bilimsel yönden eksiklerini ortaya koymak, ulusal ve uluslararası bilgi paylaşım platformlarında yer edinmesi noktasında dergiye yardımcı olmak.

2) Dergide yer alacak yazıların hazırlanmasında hem metodolojik hem de veri toplama teknikleri açısından mesleki ve akademik çevrelerin alanla ilgili yazılarında belirli standartları yakalamayı desteklemek.

3) Arşiv bilimi konu listelerini ilgili çevrelere duyurarak, çalışılmayan konular için yazıların yayınlanmasını teşvik etmek.

4) Dergi editörlerinin yayınlanmasını planladıkları yazıları daha detaylı inceleyip, derginin bilimsel niteliğini yükseltmelerinde yardımcı olmak.

5) Derginin ulusal ve uluslararası tarama dizinlerinde yer edinmesi için gereken ön yetkinlikleri göstermek.

Günümüz araştırma konularının/teknolojilerinin Bilgi ve Belge Yönetimi Bölümleri için önemi büyüktür; ancak arşivcilik alanında çalışanların (akdemisyen ve sahada çalışan arşivciler) çoğunun arşivcilik alanına dair gelişmeleri yorumlamayı göz ardı ettiği ve bunun arşivcilikle ilgili yayın yapan dergilere de yansıdığı görülmektedir. Kısıtlı imkânlarla yayın hayatına devam eden derginin yayınlanacak olan sayılarında arşivcilikle ilgili problemleri ve gelişmeleri değerlendiren yazıların yayınlanması ilkesinin benimsenmesi ve bunun ısrarlı bir şekilde sürdürülmesi beklenmektedir. Sadece sayının içeriğini doldurmak maksadıyla arşivcilik konuları dışındaki farklı içerikli yazıların dergide yer alması yayın politikasının güçlü şekilde eleştirilmesini beraberinde getirmektedir. Diğer yandan, Türk Arşivciler Derneği mensuplarının ve Devlet Arşivleri Genel Müdürlüğü çalışanlarının genellikle tarih kökenli olmaları söz konusu Arşiv Dünyası dergisinin yayın politikasının belirleyici bir durumu da beraberinde getirdiği söylenebilir. Yine bahsi geçen dernek ve kurum mensuplarının kendi akademik mensubiyetlerinden ve çalıştıkları kurumun uzmanlık sahasından hareketle -muhtemelen arka planında kasıt barındırmayan- orta bir yol buldukları da düşünülebilir; ancak böyle bir yayın politikasının zamanla derginin yaşam döngüsüne zarar verdiği ve gerçek anlamda arşivcilik alanında çalışma yapan bilim insanlarının bu dergiye bakış açılarını olumsuz etkilediği de varsayılabilir. Yine dergiye çalışmalarını göndermesi beklenecek araştırmacıların, izlenen bu yayın politikası nedeniyle dergiyi tercih etmedikleri de akla gelmektedir. Bütün bunların derginin sosyal yapısına zarar verdiğini düşünmemek için elimizde bir neden yoktur. Araştırmanın bu problemleri ortaya çıkarması düşünülmektedir.

Türkiye'deki Bilgi ve Belge Yönetimi literatürünü içerik analizi açısından değerlendirdiğimizde, yapılan araştırmaların büyük ölçüde kütüphane bilimine yönelik olduğu 
görülmektedir. Arşivcilikle ilgili içerik analizi çalışmalarının ise şimdiye kadar tamamen ihmal edilmiş olduğu görülmektedir. Bu da, arşivcilik bilimine yönelik içerik analizi çalışmalarının yapılması gerekliliğini güçlü bir şekilde ortaya koymaktadır; ancak bu çalışmayı yaparken kütüphanecilik alanında yapılan içerik analizi çalışmalarının arşivcilik alanında yapılacak içerik analizi çalışmaları bakımından örnek ve model teşkil etmesi mümkündür.

Bilgi ve belge yönetimi kavramı arşivcilik, kütüphanecilik ve dokümantasyon ve enformasyon alanlarının Türkiye'deki ortak üst adıdır. Bu şemsiye kavramın bütünsel yapısı altında yer alan arşivcilik, kütüphanecilik ve dokümantasyon ve enformasyon alanları, kendilerine özgü uygulama farklılıklarına karşın genelde kavramsal olarak birbirine yakın konuları ele almaktadır. Dolayısıyla bu durum, kütüphanecilik ve dokümantasyon ve enformasyon konularına ilişkin içerik analizi çalışmalarının incelenmesini, arşivcilik alanında yapılacak içerik analizi araştırmalarının da daha kolay yapılmasını mümkün hale getirebileceği şeklinde değerlendirilebilir. Kısacası, arşivcilik araştırma konularının belirlenmesi, kütüphane bilimi çalışmalarında sonuçlandırılmış içerik analizi çalışmalarının incelenmesini ve uygun şekilde arşiv bilimine uyarlanmasını gerektirmektedir.

Türkiye' de kütüphane biliminin içerik analiziyle ilgili olarak şimdiye kadar üç ayrı çalışma yapılmıştır. Yapılan kütüphane bilimi içerik analizi araştırmalarının ilkini Yıldız Çakın’ın 1980 yılında hazırladığı “Türk Kütüphaneciler Derneği Bülteni’nin İçerik ve Yazar Yönünden Değerlendirilmesi” adlı bilim uzmanlığı tezi oluşturmaktadır. Bu tezde Türk Kütüphaneciler Derneği Bülteni'nde 1952-1971 yılları arasında yayınlanan 502 makale içerik ve yazar açısından analiz edilmiştir. Belirlenen 23 konu içinde "Arşiv" olarak ifade edilmiş olan arşivcilikle ilgili sadece bir konu bulunmaktadır (Çakın, 1980, s. 20).

İkinci çalışma Aysel Yontar (1998) tarafından yapılmıştır. Aysel Yontar, çalışmasını Kütüphanecilik Dergisi: Belge Bilgi Kütüphane Araştırmaları'nda yayınlanan “Türkiye'de Kütüphane ve Bilgi Bilimi Konusundaki Başlıca Araştırma Sorunlarının Lisansüstü Tezlerinde Yansıması” başlığı altında 1998 yılında kaleme almıştır. Bu makalede Ankara Üniversitesi, Hacettepe Üniversitesi ve İstanbul Üniversitesi Kütüphanecilik bölümlerinde 1958-1994 y1lları arasında hazırlanan 110 yüksek lisans ve doktora tezinin içerik analizi sunulmaktadır. Söz konusu çalışmada (Yontar, 1998, s. 11); lisansüstü tezlerinde incelenen konuların dağılımı 8 başlık altında verilmiştir. "Diğer Çalışmalar” başlığı altında kütüphane bilimiyle ilgili olmayan konular değerlendirilmektedir. Arşivcilik alanındaki konular da bu kısımda ele alınmıştır.

Üçüncü çalışma ise, Aysel Yontar ve Mesut Yalvaç'ın ortak çalışması olan ve 2000 yılında yayınladıkları "Türkiye’de Kütüphane ve Bilgi Bilimi Konusundaki Araştırma Sorunları: 1952-1994 Yıllarında Yayınlanan Dergi Makalelerinin İçerik Analizi” başlıklı makaledir. Bu makalede (Yontar ve Yalvaç, 2008, s. 172-174) 517 mesleki makale ve 127 araştırma makalesi 11 farklı konu şeklinde içerik analizi ile değerlendirilmiştir. 


\section{Tarihçe ve Literatür Değerlendirmesi}

Son zamanlarda yaygın olarak kullanılmakta olan bibliyometri terimi ilk kez Alan Pritchard tarafindan 1969 yılında"Statistical Bibliography or Bibliometrics/İstatistiksel Bibliyografya mı Bibliyometri mi?"” adlı makalesinde kullanılmıştır. Bu terim her ne kadar 1969 yılında ilk kez kullanılmış olsa da, terimin istatiksel bibliyografya olarak veya bu tarz bir isimlendirme olmaksızın ilk kullanılışı 1890'lı yıllara dayandırılmaktadır. Frank Campbell'in (1986, s. 57) 1896 yılında The Theory of National and International Bibliography adlı eserinde literatür sınıflandırma düşüncesini ortaya koyması, istatistiksel bibliyografya olarak bibliyometrinin 19 . yüzyılın sonlarına kadar götürülmesini mümkün kılmaktadır. Campbell'dan sonra 1917 y1lında F. J. Cole ve Nellie B. Eales, 1550-1860 yılları arasında karşılaştırmalı anatomi sahasında literatürün artmasını bibliyografik atıflarla, istatistiksel olarak incelemişlerdir. E. W. Hulme (Statistical Bibliography in Relation to the Growth of Modern Civilization), 1923'te istatistik bibliyografyası terimini kullanmıştır. Hulme, bu kavramı, bilim ve teknolojinin tarihsel sürecinin daha iyi anlaşılabilmesinin belgelerin sayılması yöntemiyle daha kolay bir şekilde yapılabileceği düşüncesiyle kullanmıştır (Garfield, 1973, s. 137; akt.: Osareh, 1996, s. 149).

Daha sonraları bibliyometri şeklinde ifade edilecek olan bibliyografik çalışmalar Hulme'dan sonra da devam etmiştir. Eugene Garfield tarafindan 1961 yılında kurulan Institute for Science Information (ISI) ve buraya bağlı bir araştırma merkezi olan Science Citation Index'in (SCI) 1963 yılında oluşturulması (Roemer ve Borchardt, 2015, s. 28-31) bibliyometri çalışmalarının kurumsal bir kimliğe kavuşturulmasını sağlamıştır. Bibliyometri kavramı, Alan Pritchard tarafından ancak 1969 yılında açıkça kullanılmasından sonra yaygınlaşmıştır; ancak bibliyometri terimimin Pritchard'tan önce Paul Otlet tarafindan 1934 yılında ortaya atıldığ da ifade edilmektedir. Otlet (1934, bölüm 124, s. 13-22), “Traitée de Documentation. Le livre sur le Livre. Theorie et Pratique" adlı Fransızca çalışmasında "Le Livre et la Mesure. Bibliometrie" şeklinde bir başlık kullanmıştır. Bu nedenle, terimi ilk kez ve açıkça kullanan kişinin Paul Otlet olduğu ifade edilir (Hood ve Wilson, 2001, s. 292-293). Paul Otlet yerine terimi ilk kullanan kişinin Alan Pritchard olarak bilinmesi veya yaygın şekilde kabul edilmesi, muhtemelen İngilizce'nin bilimsel iletişim diline hâkim olması, Otlet'in Fransızca olan çalışmasının göz ardı edildiğinin veya söz konusu eserin sapa bir yerde basıldığının, bu sebeple de fazla bilinmediğinin göstergesi olabilir. Terimi ilk kullandığı yaygın şekilde kabul edilen Pritchard'a göre bibliyometri, "matematiksel ve istatiksel metodların kitaplara ve yazılmış diğer iletişim formlarına uygulanması" dır (Sengupta, 1992, s. 75-76). İngiliz Standartlar Enstitüsü (The British Standards Institution) (1976, s. 7) ise, 1976 y1linda bibliyometriyi, "belgelerin ve yayın modellerinin incelenmesinde matematiksel ve istatistiksel yöntemlerin uygulanması"olarak ifade etmiştir”.

Thomson Reuters sahipliğinde Science Citation Index'de (SCI) bulunan verilere -geniş bir yelpazede analiz yapmak için büyük miktarda alıntı verisine- erişebilme imkanı Web of 
Science platformu üzerinden günümüz araştırmacılarına sunulmaktadır. Web of Science'da 100 yıl öncesinden günümüze 11.500 dergiye ilişkin bilgiler bulunmaktadır. Web of Science haricinde önemli bir veritabanı olan Elsevier'in Scopus veritabanında da 1995 yılından günümüze yaklaşık olarak 17.500 dergiye ilişkin veriler bulunmaktadır. Yine 2011 yılında başlatılan Google Scholar üzerinden Google Scholar Citations ve Google Scholar Metrics ile bibliyometrik verilere erişilebilmektedir (Holmberg, 2016, s. 21-23). İnternet ve bu veritabanlarının sağladığı kolaylık bibliyometrik çalışmaların yoğun olarak kullanılmasına imkân vermektedir. Bu yoğun kullanım İnternetin yaygınlaşmasıyla paralellik göstermektedir; çünkü bibliyometrik verilerin söz konusu veritabanları üzerinden alınması, analizlerin hızlı, kolay ve çeşitli olmasını sağlamaktadır.

Bibliyometri, bilimsel bilginin üretim, iletişim ve kullanımı süreçlerini değerlendirmek için nicel tekniklerin uygulanmasına hizmet edecek metodolojik bilgi topluluğudur. Amacı ise bilim ve araştırmanın analizine ve değerlendirmesine katkıda bulunmaktır. Bibliyometri bibliyografyanın epistemolojik kaynaklarını bulmaya yardımcı olur. Bibliyografyayı uygularken bilgi kaynaklarının değerlendirilmesi için bir ölçüm faktörü oluşturan bibliyometri, araştırmayı değerlendirmek için kullanılabilecek bir yöntem veya yöntem kümesinden meydana gelir (Carrizo-Sainero, 2000, s. 1-6).

Bibliyometrinin çeşitli türleri vardır. Bu türler,Nicholas ve Ritchie (1978) tarafından tanımlayıcı (betimsel) bibliyometri ve davranışsal bibliyometri olmak üzere ikiye ayrılarak açıklanmaya çalışılmıştır. Betimsel bibliyometride, ülkeler, yazarlar, yayınlar, eserlerin yayın yılları ve literatürün konularına göre analiz edilmesi söz konusudur. Davranışsal bibliyometride ise, yazarların ve eserlerin ilişkisel olarak atıf ve referans yönünden incelenmesi ele alınmaktadır (Y1lmaz, 1999, s. 25-26). Betimsel bibliyometri ise, literatürün konulara göre analiz edilmesi ve ele alınan materyalin içerik olarak değerlendirilmesidir. Bundan dolayı, içerik analizi çalışmalarını betimsel bibliyometri olarak ifade etmek mümkündür. Betimsel bibliyometri çalışmalarının genellikle içerik analizi şeklinde ifade edilmesi de materyalin içerik olarak değerlendirmesini yansıtmaktadır.

Literatürü analiz eden içerik analizi çalışmalarının sayısı bir hayli fazladır. Kütüphanecilik literatürünü içerik analizi ile değerlendiren bir çalışma, Çin’de 1987 yılında yapılmıştır. Çin'de 1985 yılında yayınlanmış olan üç ayrı kütüphanecilik dergisi için böyle bir çalışmanın yapıldığı bilinmektedir (Cooper, 1987, s. 194-202; akt.: Abu Isneineh, 1996, s. 25). 1988 yılında ise ABD'deki 9 kütüphanecilik dergisinin konu yönelimleri incelenmiştir (Atkins, 1988, s. 633-658; akt.: Abu Isneineh, s. 26). Yine 1988'de Library Trends'in 1952-1986 y1lları arasındaki sayıları yazarlık, konu içeriği ve cilt indeksleri açılarından incelenmiştir (Lawrence Auld, 1988, s. 26). 1990 yılında ise kütüphanecilik çalışmalarında kullanılan içerik analizi yöntemi değerlendirilmiştir (Allen ve Reser, 1990, s. 251-261; akt.: Abu Isneineh, 1996, s. 29-30). 1990 yılında Finlandiya' da yapılan bir çalışmada da kütüphanecilik dergilerinin içerik 
analiziyapılmıştır (Jarvelin ve Vakkari, 1990, s. 395-421; akt.: Abu Isneineh, 1996, s. 27-28). 1991 yılında yine Finlandiya' da 1975 yılına ait kütüphanecilik araştırmalarının 30 temel kütüphanecilik dergisi üzerinde yapılması gerçekleştirilmiştir (Kumpulainen, 1991, s. 59-76; akt.: Abu Isneineh, 1996, s. 29). 1991 yılında ABD'de yapılan bir çalışmada ise Association of College and Research Libraries' in üç konferansında sunulan çalışmalar incelenmiştir (Snelson ve Talar, 1991, s. 467-472; akt.: Abu Isneineh, 1996, s. 29). Bunlar arasinda Kalervo Jarvelin ve Pertti Vakkari'nin 1990 (s. 395-421) ve 1993 (s. 129-144) yılında yayınlanan iki makalesi önemlidir. Bu çalışmalardan ilki 1990 (s. 395-421) yılında hazırlanmış olan "Content Analysis or Research Articles in Library and Information Science” adlı makaledir. Bu makalede; 37 önde gelen uluslararası Kütüphane ve Bilgi Bilim (KBB) dergilerinde sadece bir yıl içerisinde (1985) yayınlanan 833 makale incelenmiştir. Araştırmada bir akademik makalenin çeşitli yönlerini kodlamaya yönelik daha ayrıntılı yaklaşımlar sergilenmesi daha önceki çalışmaların temel eksiklerini tamamlama amacı taşımaktadır. Bu çalışmada makalelerin daha küçük bir bölümünü sistematik olarak analiz ederek 11 ana araştırma konusu olarak sınıflandırılması ve bu sınıfların bir kısmının daha alt konulara ayrılması çalışmayı daha da önemli hale getirmektedir. Jarvelin ve Vakkari, bir makalenin yaklaşımı (bilgi yayma bakış açısı ve toplumsal düzey) ve yöntemi ile (araştırma stratejisi, veri toplama, analiz türünü ve soruşturma türünü) de ilgilenmişlerdir. Jarvelin ve Vakkari'nin metodolojisi, KBB literatürünün nicel ampirik yöntemlerle (ancak anketler gibi yalnızca birkaç tür) egemen olma ve niteliksel yaklaşımlara ve teorik düşünceye zarar verme eğiliminde olduğu gibi güçlü ve iyi desteklenmiş gözlem yapmalarına izin vermiştir. Jarvelin ve Vakkari, arşiv alanındaki dergileri incelememişlerdir. Jarvelin ve Vakkari'nin bu çalışması, -literatürün miktarı çok küçük olmakla birlikte- farklı kodlama ve analiz seviyelerine sahip, özenle hazırlanmış ve metodolojisi iyi bir model olarak kabul edilmektedir (Harper, 2010, s. 3-4). Jarvelin ve Vakkari’nin 1993 (s. 129-144) yılında yayınlanan ikinci ortak çalışmalarında elde edilen bulgular 1990 yılındaki makaleyle dikkate değer oranda benzerdir (Harper, 2010, s. 7-8). ${ }^{3}$ Bu sebeple, Jarvelin ve Vakkari'nin 1993 yılındaki çalışmasına burada üzerinde ayrıntılı olarak ayrıca durulmamıştır. Bibliyometri açısından önemli sayılan Robin Chin Roemer ve Rachel Borchardt'ın 2015 yılında hazırladı̆̆ A 21 st-Century Librarian's Guide to Bibliometrics, Altmetrics, and Research Impact adlı kitap ve Kim Holmberg tarafindan 2016 yılında hazırlanan Altmetrics for Information Professionals: Past, Present and Future adlı kitap, bu çalışma kapsamında yararlanılan kaynaklar arasındadır.

Bilgi ve Belge Yönetimi çalışmalarının ileri düzeyde olduğu ülkelere göre betimsel bibliyometri (içerik analizi) çalışmalarına Türkiye'de daha geç bir zamanda başlanmıştır.

3 Jarvelin ve Vakkari, 1993 yılında yayınladıkları ortak makalelerinde 1990 yılındaki çalışmalarını temel alarak daha uzun süreyi kapsayacak şekilde genişlettiler. Elde edilen bulgular, dağılımların yirmi yılda dikkate değer ölçüde benzer olduğunu ve LIS'in ana odaklarının önemli ölçüde değişmediği sonucunu ortaya koydu; ancak bu süreklilik alt alanlar için geçerli değildir; çünkü alt alanlar arasında bazı belirgin değişiklikler görülmüştür. Örneğin; sınıflandırma ve dizin oluşturma araştırmalarının azaldığı, bilgiye erişim konusunun daha popüler hale geldiği belirlenmiştir. 
Türkiye'deki bibliyometri çalışmalarının 1980 yılından sonra yapılmaya başlandığı kısa bir literatür çalışması sonucunda kolayca anlaşılabilir. 1980 yılında Yıldız Çakın'ın "Türk Kütüphaneciler Derneği Bülteni (TKDB)’nin İçerik ve Yazar Yönünden Değerlendirilmesi” adlı bilim uzmanlığı (yüksek lisans) tezinde, 1952-1971 yılları arasında TKDB (Türk Kütüphaneciler Derneği Bülteni)'nin 71 sayısında taranan 502 makale içerik olarak değerlendirilmiştir. 1983 yılında Gülseven Altınörs'ün bilim uzmanlığ 1 tezinde, 1958-1982 yılları arasında İstanbul Üniversitesi, Ankara Üniversitesi ve Hacettepe Üniversitesi Kütüphanecilik Bölümlerinde yapılmış olan Bilim Uzmanlığı, Doktora ve Doçentlik tezlerinde kullanılan araştırma metodları değerlendirilmiştir. 1995 yılında Aysel Yontar (Yontar, 1995, s. 38-47; Yontar, 1998, s. 1-17) tarafından IFLA'nın 61. Genel Konferansı'nda sunulan ve 1998 yılında yazar tarafindan Türkçe olarak tekraren yayınlanan çalışmada Türkiye'de 1958-1994 yılları arası kütüphanecilik bölümlerinde yapılan 110 yüksek lisans ve doktora tezi incelenmiştir. Bu çalışmada;kütüphane ve enformasyon bilimi alanındaki başlıca araştırma sorunlarının belirlenmesi amaçlanmıştır. 1996 yılında Salah Eddin Abu Isneineh tarafindan hazırlanan yüksek lisans tezinde, Türkiye'de yayınlanan Türk Kütüphaneciliği ve Ürdün'de yayınlanan Rissalat Al-Maktaba adlı kütüphanecilik dergilerinin içerik analizi karşılaştırmalı olarak yapılmıştır. 1999 yılında Murat Yılmaz tarafından hazırlanan "Kütüphane ve Bilgibilim Açısından Bibliyometrinin Önemi” adlı yüksek lisans tezi, bibliyometri konusunun öneminin vurgulanması bakımından ayrı bir yere sahiptir. Bütün bunlar 2000'li yıllara kadar Türkiye' de yapılan betimsel bibliyometri araştırmaları bakımından önemli olan çalışmalardır.

2000'li yıllara baktığımızda Aysel Yontar ve Mesut Yalvaç'ın hazırladığı 1997 yılında (s. 165-186) Danimarka'daki IFLA toplantısında sunulan ve 2000 yılında Türkiye' de de yayınlanan çalışmada, Türk Kütüphaneciler Derneği Bülteni ve Türk Kütüphaneciliği dergilerinde 19521994 yılları arasında yayınlanan kütüphane ve bilgi bilim alanındaki bilimsel araştırmaya dayalı makalelerin içerik analizi yapılmaktadır. 2002 yılında Yaşar Tonta'nın (s. 282-320) 1987-2001 yılları arasında Türk Kütüphaneciliği dergisinde yayınlanan 238 makaleyi bibliyometrik özellikleri açısından karşılaştırması da Türkiye'de yapılmış olan önemli çalışmalar arasındadır.

Jarvelin ve Vakkari'nin çalışmaları-yukarıda da ifade edildiği gibi- yararlanılan literatürün miktarı az olmakla birlikte, farklı kodlama ve analiz seviyelerine sahip olmasından ve özenle kurgulanmış metodolojisinin örnek bir model oluşturmasından dolayı dünyada ve Türkiye' de yapılan içerik analizi çalışmaları arasında önemli bir yere sahiptir. Türkiye'de hazırlanan çalışmaların bir kısmında Jarvelin ve Vakkari'nin içerik analizi modelinin kullanıldı̆̆ı veya bu modelle beraber başka listelerin (LISA: Library and Information Science Abstracts terim listesi) de kullanıldığı hatta bir kısmında araştırmacıların bizzat oluşturdukları listeleri tercih ettikleri bilinmektedir (Karagözlü-Aslıÿ̈ksek, 2016, s. 89-90).

Arşiv Dünyası dergisinin içerik analizinin yapılmasının, bu dergide yer alan ve çeşitli konularda hazırlanmış olan yazıların belirli bir listeye göre incelenmesinin, yani bu dergide 
yayınlanan makaleleri belli bir konusal kalıba oturtmanın güçlükleri vardır; ancak bu durum, Kütüphane ve Bilgi Bilimi (Library and Information Science) alanlarında yapılan içerik analizi çalışmaları için geçerli değildir. Kütüphane ve Bilgi Bilimi’nde bilimsel iletişim araçları olan kitap, makale, tez vb. çeşitli formların-temel araştırma özellikleri göz önünde bulundurularakfarklı düzeylerde içerik analizi yöntemiyle incelenmesi birçok çalışmada görülmektedir (Walia ve Kaur, 2012, s. 2; Rochester, 2016, s. 207). Nitekim günümüzde etkin bakış açısına bağlı olarak Türkiye'de ve dünyada kütüphane biliminin yanı sıra arşivcilik bilimi de Kütüphane ve Bilgi Bilimi çatısı altında değerlendirilmektedir. Ancak Kütüphane ve Bilgi Bilimi uygulayıcılarının ve akademisyenlerinin ortaya koydukları içerik analizi çalışmaları özelde arşivcilik konularını tam olarak yansıtmamaktadır. Bu anlayışı benimseyip Türkiye'de arşivcilikle ilgili yazıların içerik analizi değerlendirmesini ele alan bir çalışma henüz bulunmamaktadır. Bununla birlikte, arşivcilik mesleğinin daha ileri düzeyde uygulanıp araştırma konusu olarak değerlendirildiği ülkelerde yapılan çalışmalara baktığımızda, arşivcilik disiplinin temel konularını belirlemeye yönelik tezler yapıldığı görülmektedir. Bu tezlerde;arşivcilik mesleğinin ileri düzeyde gelişme gösterdiği ülkelerdeki arşivcilikle ilgili yazıların yayınlandı̆̆ı (Türkiye'deki Arşiv Dünyası bağlamında değerlendirilebilecek) dergilerin içerik analizinin yapılmış olduğu bilinmektedir. Bu çalışmalardan biri olan Writney E. Berman'ın (2004) yüksek lisans tezinde American Archivist dergisinin arşivcilik literatürü açısından analizi yapılmıştır. Analizde derginin kurulduğu 1938 yılından 2002 yılına kadar olan ciltlerinin tümü yerine ciltler arasından örnekleme yapılarak değerlendirme yapılmıştır. Örneklemeye göre; 1. cilt (1938) hariç ve ilk olmak üzere 10'ar yıllık durumu değerlendirmek için 1942, 1952, 1962, 1972, 1982,1992 ve 2002 y1lına ait ciltler ele alınıştır. Böylelikle söz konusu yıllara ait toplam 8 ciltteki 96 makale yapısal ve konusal olarak incelenmiş ve derginin kurulduğu ilk günden 2002 yılına kadar gelişiminin değerlendirilmesi yapılmıştır (Berman, 2004, s. 8). Wakefield Harper'ın (2010) yüksek lisans tezinde ise dünya genelinde arşivcilik alanıyla ilgili beş önemli derginin içerik analizi yapılmıştır. Bu dergiler şunlardan oluşmaktadır: American Archivist, Archivaria, Archives and Manuscripts, Journal of the Society of Archivists ve Archival Science. American Archivist, Journal of the Society of Archivists ve Archivaria dergileri için 1978, 1988, 1998, 2008, Archives and Manuscripts için 2008 yılı uygun olmadığ için 1977, 1987, 1997, 2007 yılları seçilmiştir. Archival Science dergisi hariç ismi geçen dergiler, seçilen yıllarda yayınlanmıştır. Archival Science dergisi ise Archives and Museum Informatics dergisiyle 2001 yılında birleştirilmiştir. Archival Science dergisi için 2008 yılı seçilmiştir. Yaklaşık 30 yılı kapsayan çalışmanın örneklemi, zamansal eğilimleri belirleyebilecek kadar büyük, yönetilebilir olabilecek kadar da küçüktür.

İçerik analizi kapsamında yayınlanan yazıların değerlendirilmesi ve buna göre arşivcilik alanındaki konuların belirlenmesi, tarafımızdan ele alınan bu çalışma açısından da önem ifade etmektedir. Ayrıca bu çalışmanın bulgularının değerlendirilmesi kısmında verilen konular şu şekildedir: (1) Arşivcilik eğitimi, (2) arşivsel değerlendirme, (3) arşivsel düzenleme/ tanımlama (provenans ve arşivsel süreçlerin tartışılması ile ilgili yazılar dâhil), (4) arşivsel 
erişim (kullanıcı hizmetleri, talimatlar, arşivsel tanıtım), (5) idare/planlama/yönetim, (6) özel arşivler ve koleksiyonları (örneğin, belirli bir ülkedeki veya konudaki arşivler), (7) farklı arşivleme formatları (dijital doğan malzemeler, mikrofilm, fotoğraflar gibi), (8) arşivsel etik, siyasi ve yasal konular, (9) saklama/koruma, (10) mesleki konular (örneğin, arşiv mesleği üzerine yapılan anketler, arşivcinin rolü vb.) ve (11) biyografidir.

\section{Türk Arşivciler Derneği ve "Arşiv Dünyası" Dergisi}

1998 yılının Nisan ayında Devlet Arşivleri Genel Müdürlüğü Osmanlı Arşivi Daire Başkanlığı çalışanları tarafından Tüm Arşivciler Derneği adıyla faaliyete geçen dernek, kurulduğu günden itibaren Türkiye'de arşivcilik mesleğinin tanıtımı, meslek mensuplarının sosyal saygınlığının artırılması ve kurumların arşiv hizmetlerine rehberlik çalışmalarının yanı sıra Osmanlı Türkçesi eğitim seminerleri düzenlemek suretiyle arşiv malzemesinin okunup değerlendirilebilme becerisini geliştirmeye yönelik çalışmalar yapan; alanında tek sivil toplum kuruluşu olma özelliğini taşımaktadır. ${ }^{4} 2006$ yılında isim değişikliğine giderek Türk Arşivciler Derneği adını alan Dernek (2017), “Türk” ibaresini (Dernekler Yönetmeliği, 2005) isim olarak kullanma iznini ilgili birçok kurumun olumlu görüşü ve İçişleri Bakanlığının 11/09/2006 tarihli onay yazısı ile almıştır (Şahin, 2006, s. 3).

Türk Arşivciler Derneğinin misyonu şu şekilde belirtilmektedir (Türk Arşivciler Derneği, 2017):

- Arşivcilik alanlarında bilimsel-mesleki çalışmalar ve yayımlar yaparak bunları toplumun tüm kesimlerine duyurmak.

- Çok disiplinli hale gelen arşivcilik hizmetlerinin önemini topluma benimsetmek.

- Meslek ile ilgili gelişmeleri yakından takip ederek meslek elemanlarını ve toplumu gelişmelerden haberdar etmek, bilgilendirmek.

- Meslektaşlar arasında dayanışma ve uyumu sağlamak.

- Mesleki ahlak ilkelerinin uygulanmasını sağlamak.

- Arşivcilik ve ilgili alanlarda milli ve milletlerarası kuruluşlar ile iş birliği içine girerek çalışmaları dünya geneline yaymak.

- Arşiv dokümanının muhafazası, tasnifi, araştırmaya arzı ve standart dosya planları konusunda kamu kurum ve özel kuruluşlarına rehberlik etmek.

- Yurt içinde ve yurt dışında gerek kamu ve kuruluşlarında, gerekse özel arşivlerde yapılacak olan araştırma ve faaliyetlere danışmanlık, rehberlik, gözetim, denetim ve organizasyon hizmeti vermek ve iş birliği yapmak.

4 Bu derneğin yanı sıra Arşiv Çalışanları Derneği adıyla Ankara'da yeni bir dernek kurulması için teşebbüste bulunulmuş, kısa süre için aktif olabilmiş ancak faalişetlerini sürdüremeyerek kısa süre sonra kapanmıștır. 
Türk Arşivciler Derneği, ayrıca arşivcilik, belge ve bilgi hizmetleri alanlarında; arşivcilik mesleğinin prensipleri ve teknikleri çerçevesinde katılıma, paylaşıma ve ekip çalışmasına dayalı bir anlayışla arşivcilik dünyasına öncülük etmek vizyonuna sahiptir.

Türk Arşivciler Derneğinin yönetim kurulu, Yönetim Kurulu Başkanı olarak sorumluluk alan bir başkan ile beraber iki başkan yardımcısı, bir sekreter, iki üye ve bir muhasip olmak üzere yedi kişilik bir heyetten oluşmaktadır.

Türk Arşivciler Derneği tarafından mesleki etik kurallarına ilişkin bir çalışma yapılmıştır. $\mathrm{Bu}$ çalışmanın içeriği dernek internet sayfasından kamuoyu ile şu şekilde paylaşılmıştır (Arşivder, 2017):

- Arşivcilik alanında yürütülen her türlü çalışmaları mesleki prensipler ve yasalar çerçevesinde yerine getirmek.

- Mesleki gelişmeleri takip etmek ve bu hususta öneriler geliştirmek.

- Şahıs, devlet ve millet haklarının korunması ve bunları düzenleyen yasalara bağlı kalmak.

- Arşiv malzemesine ait her türlü bilgiyi araştırma vasıtalarıyla kullanıma sunmak.

- Arşiv malzemesinin erişime sunulmasında din, dil, rrk, cinsiyet gibi nedenlerden hiç kimseye ve zümreye ayrım yapmamak, bu alandaki kriterlere bağlı kalmak.

- Arşiv malzemesinin hizmete sunum önceliği konusunda bireysel taleplerden ziyade kamuoyu ve devletin taleplerini ön plana almak.

- Ülke ve dünya arşivlerinin savaş, yangın, sel vb. nedenlerle yok olma ya da yağmalanma gayretlerinin önlenmesine yönelik her türlü tedbir ve faaliyetin içerisinde yer almak.

Türk Arşivciler Derneği, arşivcilik alanında yürütülen her türlü çalışmaları mesleki prensipler ve yasalar çerçevesinde yerine getirmek, mesleki gelişmeleri takip etmek ve bu hususta öneriler geliştirmek amacıyla çeşitli kurslar açmaktadır. Bunlar, Osmanlı Türkçesi, Belge ve Eski Kitap Restorasyonu ve Arşivcilik kurslarıdır.

Türk Arşivciler Derneği, 3473 sayılı “Muhafazasına Lüzum Kalmayan Evrak ve Malzemenin Yok Edilmesi Hakkında Kanun Hükmünde Kararnamenin Değiştirilerek Kabulü Hakkında Kanun"5 kapsamındaki mükellef Kamu Kurum ve Kuruluşları (ayrıca mükellef olmayan kamu

519 Ekim 1984 tarihinde yürürlüğe konulan 3056 sayılı Başbakanlık Teşkilât Kanunu ile Türk arşivlerinin korunması ve değerlendirilmesi ile ilgili her türlü görev Başbakanlığa verilmiş, bu görevi yürütmek üzere Devlet Arşivleri Genel Müdürlüğü kurulmuş ve Osmanlı Arşivi Daire Başkanlığı, Genel Müdürlüğe bağlanmıştı. Yine Genel Müdürlüğe bağlı Cumhuriyet Arşivi Daire Başkanlığı; Milli Mücadele, TBMM hükûmeti ve Cumhuriyet dönemine ait, 3473 sayılı "Muhafazasına Lüzum Kalmayan Evrak ve Malzemenin Yok Edilmesi Hakkında Kanun" kapsamındaki kurum ve kuruluşlar bünyesinde yer alan arşiv malzemesinin, tespiti, korunması, düzenlenmesi ve değerlendirilmesi konusunda gerekli ilmi ve teknik hazırlık ve çalışmaları yerine getirmek ve denetlemekten 
kurum ve kuruluşları) ile Özel Kurum ve Kuruluşlara yönelik olarak bazı konularda eğitim ve rehberlik faaliyetlerinde bulunmaktadır. Bu eğitim konuları şunlardan oluşmaktadır:

- Temel arşivcilik bilgileri.

- Mevzuat (3473 Sayıl1 "Muhafazasına Lüzum Kalmayan Evrak ve Malzemenin Yok Edilmesi Hakkında Kanun”, 19816 Sayılı “Devlet Arşiv Hizmetleri Hakkında Yönetmelik”, "Haberleşme Kodu Uygulaması ile ilgili Başbakanlık Genelgesi”, “2005/7 sayılı Standart Dosya Planı Konulu Başbakanlık Genelgesi”). ${ }^{6}$

- Dosya planı hazırlama usulleri.

- Mükellef kurumlarda Standart Dosya Planı ve uygulaması.

- Dosyalama yöntemleri.

- EBYS (Elektronik Belge Yönetimi Sistemleri).

- Arşiv mekânlarının düzenlenmesi ile ilgili standartlar (özellikle 13212 nolu standart).

- Birim arşivi işlemleri.

- Kurum arşivi işlemleri.

- Ayıklama ve imha işlemleri.

- Devir işlemleri.

sorumlu daire başkanlığı olarak faaliyetlerine devam etmekteydi. 9 Temmuz 2018 tarih ve 30473 sayılı Resmi Gazete'de yayınlanan 703 sayılı Kanun Hükmünde Kararname gereğince 3056 sayılı Başbakanlık Teşkilatı Hakkında Kanun Hükmünde Kararnamenin Değiştirilerek Kabulü Hakkında Kanun yürürlükten kaldırılmış ve Başbakanlık merkez teşkilatı kapatılmıştır. Böylece Başbakanlık merkez teşkilatı olan Devlet Arşivleri Genel Müdürlüğü de kapatılmıştır. 16 Temmuz 2018 tarih ve 11 numaralı Cumhurbaşkanlığı Kararnamesi ile Devlet Arşivleri Başkanlığı Cumhurbaşkanlığına bağlı bir başkanlık olarak kurulmuştur (Devlet Arşivleri Başkanlığı, 2019). Dolayısıyla 3473 sayılı kanun kapsamındaki mükellef kamu kurum ve kuruluşları, Devlet Arşivleri Başkanlığı Hakkında Cumhurbaşkanlığı Kararnamesi (11 nolu kararname) ile yeniden şekillenmiştir. Kararnameyle mükellefiyeti olmayan kurumlar da Devlet Arşivleri Başkanlığının mükellefleri olmuştur. 3473 sayılı kanunda Milli Savunma Bakanlığı, İçişleri Bakanlığı ve Dışişleri Bakanlığının mükellefiyetleri olmazken söz konusu Kararnameyle bu bakanlıklara da Devlet Arşivleri Başkanlığının mükellefleri statüsüne geçirilmişlerdir. Türkiye Büyük Millet Meclisi ve Milli İstihbarat Teşkilatı Başkanlığı hariç olmak üzere tüm kamu kurum ve kuruluşları Kararnameyle Devlet Arşivleri Başkanlığına karşı sorumlu hale getirilmiştir. Yine noter kurumları gibi kamu kurumu niteliğindeki meslek kuruluşları ile vergi muafiyeti tanınan vakıflara ve kamu yararına çalışan derneklere de mükellefiyet getirilmiştir (Devlet Arşivleri Başkanlığı Hakkında Cumhurbaşkanlığı Kararnamesi, 2018).

63473 sayılı Kanun'un getirdiği hükümlerin uygulanmasını temin etmek maksadıyla Devlet Arşiv Hizmetleri Hakkında Yönetmelik Başbakanlıkça hazırlanarak 16.05.1988 tarihinde yürürlüğe konulmuştu. Devlet Arşivleri Genel Müdürlüğü kapatılıp yerine Devlet Arşivleri Başkanlığı kurulunca, genel müdürlük mevzuatı başkanlık mevzuatı ile yeniden şekillenmiştir. Türk Arşivciler Derneği söz konusu mevzuat eğitimlerini 3473 Sayılı "Muhafazasına Lüzum Kalmayan Evrak ve Malzemenin Yok Edilmesi Hakkında Kanun" ve 19816 Sayılı "DevletArşiv Hizmetleri Hakkında Yönetmelik" uygulanmayacağı için 11 nolu Cumhurbaşkanlığı Kararnamesi ve 30922 sayılı yeni yönetmeliğe göre revize etmeleri gerekecektir. Ayrıca 1 nolu Cumhurbaşkanlığı Kararnamesinde yeniden şekillenen idari yapının da eğitim programlarına dâhil edilmesi gerekecektir. 
Türk Arşivciler Derneği kuruluşundan itibaren yayın faaliyetleri de gerçekleştirmektedir. Tüm Arşivciler Derneği Bülteni'ni (daha sonra Arşiv Dünyası dergisi) 1999 yılından beri yılda iki defa olmak üzere yayınlayan Türk Arşivciler Derneği, bu Bülten'in devamı olan Arşiv Dünyası dergisini 2008 yılından itibaren hakemli bir dergi olarak yayınlamaktadır. Yılda iki defa yayınlama amacını taşımasına rağmen düzenli yayınlanmayan dergi, günümüze kadar toplam 17 sayı olarak yayınlanabilmiştir. 14.-15. ve 16.-17. sayıları da birleştirilerek basılmıştır. Başta DAGM Osmanlı Arşivi Daire Başkanlığı (artık Devlet Arşivleri Başkanlığı Kağıthane Yerleşkesi) çalışanları olmak üzere, üniversitelerin Bilgi ve Belge Yönetimi (BBY) Bölümü öğretim üyelerinin de yazılarının yayınlandı̆̆ı dergi, üniversitelerden gelen çeşitli (BBY bölümleri haricinde) yazıları da içermektedir.

\section{Araştırmanın Amacı, Önemi ve Yöntemi}

\subsection{Araştırmanın Amacı ve Önemi}

$\mathrm{Bu}$ makalenin amacı, arşivcilik alanındaki araştırma problemlerini çeşitli açılardan ele almaktır. Bu amaçla, Arşiv Dünyası dergisinde yayınlanan hakemli ve hakemsiz yazıların içerik analizi yapılmaktadır. İçerik analizi için aşağıda belirtilen soruların cevapları aranmıştır. Bunlar;

- Dergide yayınlanan makaleler arşivciliğin hangi temel araştırma konuları ile ilişkilidir?

- Arşiv Dünyası dergisinin yayınlandığı 1999 yılından günümüze kadar dergide yayınlanan makalelerin arşivcilik açısından önemi nedir?

- Yayınlanan makalelerin yayın türü nedir?

- Yayınlanan makalelerin sayfa sayıları nasıldır?

- Yayınlanan makalelerin konuları nelerden oluşmaktadır?

- Arşiv Dünyası dergisinde yazıları yayınlanan yazarların profili nasıldır?

- Yazarların kullandığı yöntemler ve veri toplama teknikleri nelerdir?

- Makalelerde Türkçe-İngilizce öz bulundurma durumu nedir?

- Makalelerde dipnot-kaynakça verilmesine dikkat edilmiş midir?

Bu soruların cevapları arşivcilik alanında son gelişmelerin seyrini ortaya koyarak Arşiv Dünyası dergisinde yayınlanan makalelerin mesleki araştırma sorunlarını hangi bakımlardan ele aldıklarını inceleme imkânı verecektir. Ayrıca, Arşiv Dünyası dergisinin içerik analizi yapılarak yayınlanan makalelerin alana katkılarını değerlendirme imkânı olabilecek; böylece arşivcilik sahasında çalışanlara araştırma konuları ve araştırma alanları kısıtlı olan konular hakkında fikir verecektir. Arşiv Dünyası dergisindeki makaleler, arşivcilik alanının bütün konularını kapsamamaktadır. Burada yayınlanan makaleler geleneksel/klasik ve modern arşivcilik anlayışını/araştırma konularını kısmen yansıtmaktadır. Bu da, söz konusu derginin, 
araştırmacıların arşivcilik alanındaki güncel ve diğer konu seçimlerini düşük bir oranda etkileyebilecek önemde olduğunu göstermektedir. Yine bu durum, söz konusu dergide yayınlanan makalelerin arşivcilik alanında araştırma yapanlara çok fazla destek verebilecek düzeyde olmasa da, en azından bir dereceye kadar fikir vermesi ve hâlihazırda Türk meslektaşların ne tür konular üzerinde araştırmalarını yürütmekte olduklarının belirlenmesi bakımından öneme sahip olduğuna işaret etmektedir.

\subsection{Araştırmanın Yöntemi}

$\mathrm{Bu}$ araştırmada bilimsel araştırma yöntemi olarak betimsel analiz ve içerik analizi yöntemlerinden yararlanılmıştır.Veri toplama tekniği ise içerik analizidir. Çalışmada Arşiv Dünyası dergisinde 1999-2014 yılları arasında yayınlanan 169 hakemli ve hakemli olmayan makale, yayın türü, sayfa sayıları, makale konuları, makalelerde kullanılan yöntem, veri toplama tekniği, makalelerdeki Türkçe-İngilizce öz durumu, dipnot-kaynakça bilgisi ve yazarların hangi kurumlardan katkıda bulundukları bilgisi gibi toplam 8 başlık altında analiz edilmiştir. Dergi, hakemli olarak yayınlanmaya başlamadan önceki (1999-2007) araştırma yazıları hakemsiz olarak değerlendirilmiştir. Hakemli bir dergi olduktan sonra yayımlanan araştırma yazıları hakemli olarak kabul edilmiştir. Derginin 2014 yılından sonra birleşik olarak çıkan (2017) 18.-19. sayıları (tek cilt) ile 20.-21. (2018) ve 22. (2019) sayıları çalışmaya dâhil edilmemiştir. Bunun nedeni; çalışmanın bitirilme aşamasında olması ve yeni sayıların önceki sayılarla değerlendirilemeyecek (tek bir editör yerine editör kurulunun olması, e-dergi olarak TÜBİTAK ULAKBİM DergiPark'ta dizinlenmesi gibi) yenilikler taşıması ve yayın politikasında (Bilgi ve Belge Yönetimi alanına özgü bir dergi olmak ve yayınların konu yöneliminin bu çerçevede olmasını sağlamak şeklinde) meydana gelen değişikliktir.

Değerlendirilecek olan veriler, Arşiv Dünyası dergisinin yayınlanan bütün sayılarının manuel olarak Microsoft Office Excel'e üst veriler altında -sütunsal alanlar hazırlanarak-PivotChart yardımıyla grafiksel sonuçlar şeklinde ortaya konmuştur. Grafiksel sonuçlara göre elde edilen yüzdelik değerlerin Arşiv Dünyası dergisi için yorumlanması yapılmıştır. Yorumlar, Kütüphane ve Bilgi Bilim alanında hazırlanan bibliyometri çalışmalarından özellikle içerik analizli kaynaklar değerlendirilerek yapılmıştır. Büyük bir problem olarak görülen makalelerin konularına göre analizinde Wakefield Harper'ın 2010 yılında hazırladığı arşivcilik literatürünü yansıtan “A Content Analysis of Archival Journal Literature" adlı tez çalışmasında kullanılan 11 konu başlığ listesi kullanılmıştır. Arşiv Dünyası dergisinde yayınlanan makale yazarlarının kullandıkları yöntem ve veri toplama tekniği çalışmanın bir diğer önemli problemini oluşturmuştur. İncelenen yazılardaki yöntem ve veri toplama tekniği yazılardaki belirtilen şekliyle alınmıştır. Yöntem ve veri toplama tekniği belirtilmeyen yazılarda ise Jarvelin ve Vakkari'nin yöntem ve veri toplama tekniği listesinden yararlanılmıştır. Yazıların varsa öz, öz yoksa giriş kısımları değerlendirilerek kullandıkları yöntem ve veri tekniği söz konusu listeye göre sınıflandırılmaya çalışılmıştır. 


\subsection{Bulguların Değerlemesi}

\section{Yayın Türleri}

Arşiv Dünyası dergisinin 1999-2017 yılları arasında toplam 17 sayısı yayınlanmıştır. Bu 17 sayının 14.-15. ve 16.-17.sayıları birleşik sayı, yani tek cilt şeklinde yayınlanmıştır. Türk Arşivciler Derneğinin 1998 yılında kurulması ve bir sene sonra derginin ilk sayısının yayınlanması yoğun bir çalışmanın göstergesidir; ancak söz konusu derginin 2. sayısı 2003 yılında yayınlanabilmiş̧ir. Dergi, 2003 yılından 2007 yılına kadar senede iki defa olmak üzere düzenli olarak çıkmıştır. 2008 yılında hakemli olarak yayın hayatına devam etmeye başlayan dergi, hakemli olarak yayın hayatına başladığı ilk ve ikinci yıllarında birer sayı şeklinde yayınlanabilmiştir. Sonraki iki yıl boyunca da (2010-2011) da derginin yeni bir sayısı çıkarılamamıştır. 2012 senesinde tekrar yayınlanmaya başlayan dergi, sonraki 3 yıl boyunca 3 cilt olarak yayınlanabilmiştir.

2008 yilından itibaren hakemli bir dergi olarak yayın hayatına devam etmesine karar verilen derginin daha düzenli ve nitelikli olması ve bir yayın politikası çerçevesinde yayın hayatına devam etmesi düşünülmüştür. Ancak -daha önceki yıllarda da olduğu gibi- bu beklentiler gerçekleşmemiştir. Düzenli yayınlanması mükün ol(a)mayan derginin, arşiv ve arşivcilik problemlerini beklentiler doğrultusunda yansıtması da mümkün ol(a)mamıştır. Mesleki açıdan önemli bir yayın organının düzensiz bir yayın hayatıyla karşı karşıya kalması Türk arşivlerinin ve arşivciliğinin sorunlarılya ilgili önemli bir boşluğun oluşmasına neden olmuştur.

Derginin toplam 17 sayısı için farklı zamanlarda 3 farklı editörün çalıştığı görülmektedir. Bu editörler, Devlet Arşivleri Başkanlığının Kağıthane Yerleşkesinde (o zamanki adı ile Başbakanlık Devlet Arşivleri Genel Müdürlüğü Osmanlı Arşivleri Daire Başkanlığı) çalışmaktadırlar. Türk Arşivciler Derneğinin de aynı kurumdan/daire başkanlığından kişilerin gayretleriyle kurulması derginin yayınlanmasıyla ilgilenenlerin (editörlerin) bu kurumdan olmasını doğal hale getirmektedir; ancak bu durum, bir derginin varlığ için önemli kriterler arasında olan bilimsel niteliklerin dikkate alınması, önemsenmesi ilkesinin arka planda kaldığı izlenimini uyandırmaktadır. Toplam 18 senede 17 sayının çıkması aslında bunun çok açık bir göstergesidir. Hakemli olarak yayın hayatına devam eden bir derginin DAGM'de görevli bir personelin editör olması yanında üniversitelerin Bilgi ve Belge Yönetimi bölümlerinden de bir veya daha fazla editörün katkıs1 alınmak suretiyle nitelikli ve etkin bir yayın hayatına sahip olması sağlanabilirdi; ancak büyük bir özveriyle hazırlanan 17 sayı ve Türk Arşivciler Derneğinin gayretleri dergiye ilişkin düzenli yayın faaliyetlerini ve nitelik kazandırılmasını sağlamakta yetersiz kalmıştır. Bu durum, -açık bir ifade ile- özverili bütün gayretlerin önemli ölçüde heba edilmiş olduğu anlamına gelmektedir.

Derginin yıl ve sayı bilgilerine baktığımızda, 1999 yılında 1. sayı, 2003 yılında 2. sayı, 2004 yılında 3. ve 4. sayılar, 2005 yılında 5. ve 6. sayılar, 2006 yılinda 7. ve 8. sayllar, 2007 
yılında 9. ve 10. sayılar, 2008 yılında 11. say1, 2009 yılında 12. say1, 2012 yılında 13. say1, 2013 yılında 14. ve 15. sayılar (tek cilt) ve son olarak da 2014 yılında 16. ve 17. sayılar (tek cilt) şeklinde bir tablo ile karşılaşılmaktadır. Buna ait bir tablo (Tablo 1) aşağıda sunulmuştur.

Tablo 1: Yıllara göre yayın faaliyeti

\begin{tabular}{|l|c|c|c|}
\hline \multirow{2}{*}{ Yayınlandı̆̆ı Yıl } & \multicolumn{2}{|c|}{ Sayıların Yayın Şekli } & \multirow{2}{*}{$\begin{array}{c}\text { Yll İçinde Yayınlanan } \\
\text { Sayı Adedi }\end{array}$} \\
\cline { 2 - 3 } & Bă̆ımsız & Birleşik & 1 \\
\hline $\mathbf{1 9 9 9}$ & 1 & - & 1 \\
\hline $\mathbf{2 0 0 3}$ & 2 & - & 2 \\
\hline $\mathbf{2 0 0 4}$ & $3-4$ & - & 2 \\
\hline $\mathbf{2 0 0 5}$ & $5-6$ & - & 2 \\
\hline $\mathbf{2 0 0 6}$ & $7-8$ & - & 2 \\
\hline $\mathbf{2 0 0 7}$ & $9-10$ & - & 1 \\
\hline $\mathbf{2 0 0 8}$ & 11 & - & 1 \\
\hline $\mathbf{2 0 0 9}$ & 12 & - & 1 \\
\hline $\mathbf{2 0 1 2}$ & 13 & - & 1 \\
\hline $\mathbf{2 0 1 3}$ & - & $14-15$ & 1 \\
\hline $\mathbf{2 0 1 4}$ & - & $16-17$ & \\
\hline
\end{tabular}

Arşiv Dünyası dergisinde yayınlanan toplam 19 yayın türü vardır. Bu yayın türlerine ilişkin toplam yayın adedi sayısı ise 294'tür. Yayın türlerine sayıca baktığımızda (Şekil 1)-alfabetik olarak- anma toplantısı $3(\% 1,02)$, basın bildirisi $2(\% 0,68)$, diğer $4(\% 1,36)$, editör yazısı $15(\% 5,10)$, faaliyet $3(\% 1,02)$, gezi $6(\% 2,04)$, haberler $11(\% 3,74)$, hakemli makaleler 72 $(\% 24,49)$, hakemsiz makaleler $97(\% 32,99)$, iktibas $5(\% 1,70)$, kitap tanıtımı $36(\% 12,24)$, konferans $3(\% 1,02)$, mülakat (görüşme) $16(\% 5,44)$, sempozyum programı $1(\% 0,34)$, serbest yazı $8(\% 2,72)$, sergi $2(\% 0,68)$, televizyon programı $2(\% 0,68)$, yeni yayınlar $1(\% 0,34)$ ve yönetim kurulu başkanı yazısı $7(\% 2,38)$ şeklinde bir sonuç ortaya çıkmaktadır. 


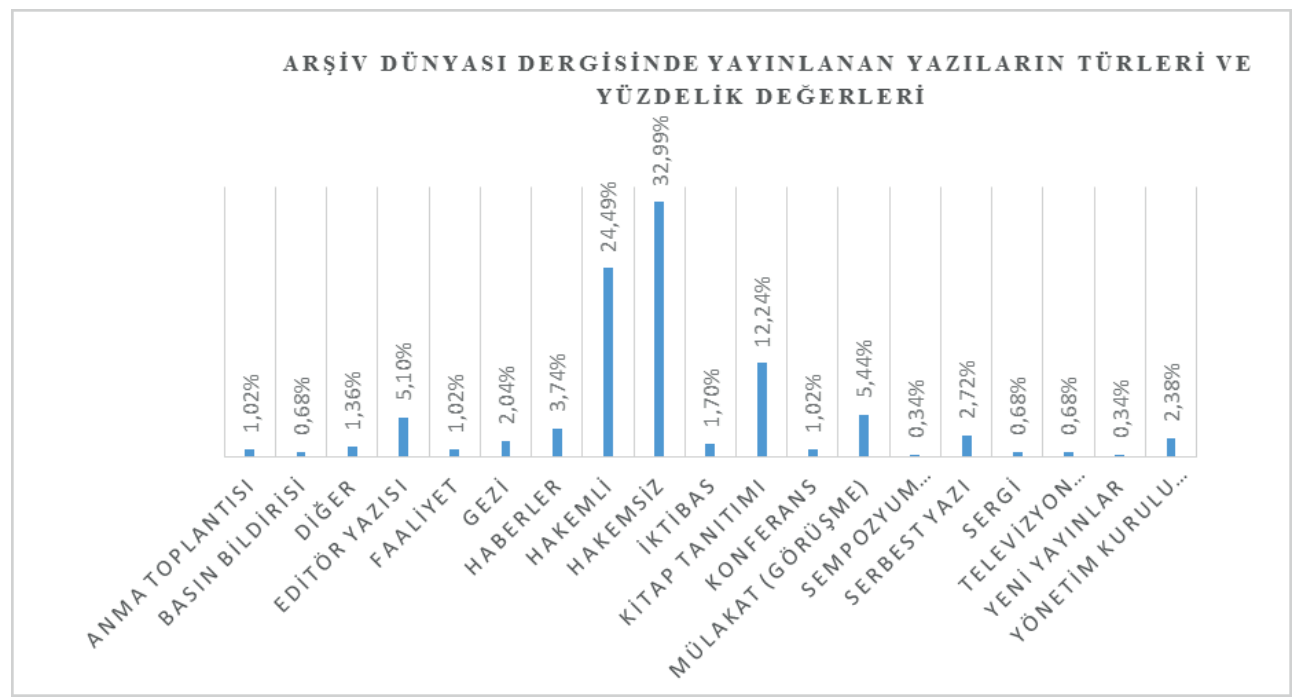

Şekil 1: Arşiv Dünyası dergisinde yayınlanan yazıların türleri

Hakemli ve hakemsiz makalelerin toplamda \%57,48 oranında olması, dergide yayınlanan mesleki ve araştırmaya dayalı yazıların belirgin bir yayın ağırlığına sahip olduğunu göstermektedir. Derginin analiz sürecinde dikkat çekici önemli noktalardan bir diğerini kitap tanıtım yazıları oluşturmaktadır. \%12,24 şeklinde kayda değer bir oranda olan kitap tanıtımlarının birçoğunun arşivcilik alanıyla ilgili olmayan yayınları içermesi söz konusudur. Arşivcilik mesleğiyle ilgili bulunmayan kitap tanıtımları sayıca yüksek orandadır. Bu oranda olmasa bile alanı yansıtan çalışmaların tanıtılması tercih edilebilirdi. Bu durum, Arşiv Dünyası dergisinin imajına zarar vermekle kalmamakta aynı zamanda sayıların ilgisiz konulardaki yazılarla gereksiz şekilde abartıldığg izlenimini de uyandırmaktadır.

\section{Sayfa Sayılart}

Arşiv Dünyası dergisinin toplam 17 sayısı (1999-2014) 1.189 sayfa olarak yayınlanmıştır. Derginin hakemli olmadığı zamanlardaki toplam sayfa sayısı 636'dır (\%53,49). 636 sayfa derginin 1.-10. sayılarının toplam sayfa sayısıdır. Hakemli olduktan sonra yayınlanan toplam sayfa sayısı 553’tür (\%46,50). 553 sayfa 11.-17. sayılarının toplam sayfa sayısıdır. Toplam sayfa sayısının dergi sayılarına göre ortalaması 69,94'tür. Hakemli olmadan önceki sayıların sayfa ortalamaları 63,6' dır. Hakemli olduktan sonraki sayıların ortalama sayfa sayısı 79 olmakla beraber hakemli olduktan sonra 4 sayının (14. ve 15. ile 16. ve 17. sayıların) birleşik olarak 2 ciltte basılmasından dolayı, hakemli cilt sayısı 5 'tir. Sayfa ortalaması alındığında 110,6 sayfadır. Arşiv Dünyası dergisinin dergi sayılarına göre sayfa ortalamaları yüksektir. Yayın sayılarına göre sayfa ortalamaları alındığında toplam 294 yayın başına düşen sayfa ortalaması 4,04'tür. 
Tablo 2: Arşiv Dünyası dergisinin yıllara ve sayılara göre sayfa sayıları ve hakemli durumu.

\begin{tabular}{|c|c|c|c|c|c|}
\hline \multirow{2}{*}{ Yayınlandı̆̆ı Yıl } & \multicolumn{2}{|c|}{ Sayıların Yayın Şekli } & Sayfa Sayısı & \multicolumn{2}{c|}{ Sayının Hakem Durumu } \\
\cline { 2 - 6 } & Bağımsız & Birleşik & & Hakemli & Hakemsiz \\
\hline $\mathbf{1 9 9 9}$ & 1 & - & 24 & & Hakemsiz \\
\hline $\mathbf{2 0 0 3}$ & 2 & - & 12 & & Hakemsiz \\
\hline $\mathbf{2 0 0 4}$ & $3-4$ & - & $24-40$ & & Hakemsiz \\
\hline $\mathbf{2 0 0 5}$ & $5-6$ & - & $56-40$ & & Hakemsiz \\
\hline $\mathbf{2 0 0 6}$ & $7-8$ & - & $72-80$ & & Hakemsiz \\
\hline $\mathbf{2 0 0 7}$ & $9-10$ & - & $152-136$ & & Hakemsiz \\
\hline $\mathbf{2 0 0 8}$ & 11 & - & 144 & Hakemli & \\
\hline $\mathbf{2 0 0 9}$ & 12 & - & 133 & Hakemli & \\
\hline $\mathbf{2 0 1 2}$ & 13 & - & 112 & Hakemli & \\
\hline $\mathbf{2 0 1 3}$ & - & $14-15$ & 92 & Hakemli & \\
\hline $\mathbf{2 0 1 4}$ & - & $16-17$ & 72 & Hakemli & \\
\hline Toplam sayfa sayısı & & & $\mathbf{1 1 8 9}$ & $\mathbf{5 5 3}$ & $\mathbf{6 3 6}$ \\
\hline
\end{tabular}

\section{Makale Konulart}

Dergiler, faaliyet gösterdikleri alanlara yönelik bilimsel yaklaşımların bilinmesi, yayılması ve problemlerin çözülmesi için önem arz etmektedirler. Dergilerde yayınlanan yazılar, alandaki eksiklerin belirlenmesi ve giderilmesi ile mesleki bilginin geliştirilmesi için temel bilimsel iletişim araçları olarak değerlendirilebilir. Bu araçların, dergilerin yayın hayatındaki etkinliğini sağladıkları bilinmektedir. Dergilerde mesleki alanla ilgili konuların tartışılması, yazıların yayınlanması, olması gereken önemli bir niteliktir. Bunun haricinde derginin amacını sergilemeyen ilgisiz konuların dergide yayınlanması, derginin yaşam döngüsünü sekteye uğratabilecek ciddi engellerdendir. Bu engellerin belirlenmesi ve bu bilinçle hareket eden editör ve yayın kurulunun dergide yayınlanan konulara dikkat etmeleri gerekirdi. Zamanla belirli bir yayın kalitesini yakalayan dergilerde ilgisiz yazıların varlığı asgariye indirgenmekte veya bu tür yazılara yer verilmemektedir. Arşiv Dünyası dergisindeki konulara bakıldığında arşivcilikle ilgili olmayan konuların yoğunlukta olduğu görülmektedir. Dergide yayınlanan hakemli ve hakemsiz olmak üzere toplam 169 yazıdan 88'i $(\% 52,07)$ arşivcilikle ilgili olmayan konuları oluştururken, 81'i $(\% 47,93)$ ise arşivcilikle ilgili konulardan oluşmaktadır.

Arşiv Dünyası dergisinde yer verilen ve arşivcilikle ilgisi bulunmayan yazılar haricinde, arşivcilikle ilgili olan yazıların arşiv bilimi için öneminin değerlendirilmesi, derginin isminden hareketle akla gelen kendi öz kitlesi için gereklidir. Söz konusu dergide çeşitli konularda yer verilen yazıları belirli bir listeye göre incelemek mümkün olmadığından, bu durum, Kütüphane ve Bilgi Bilimi alanlarında yapılan içerik analizi çalışmalarının değerlendirilmesinin önemine işaret etmektedir. Nitekim günümüzde Türkiye'de ve dünyada Kütüphane ve Bilgi Bilimi 
mensupları arasında arşivcilik bilimi Kütüphane ve Bilgi Bilim çatısı altında görülmektedir. Bundan dolayı Kütüphane ve Bilgi Bilimi uygulayıcılarının ve akademisyenlerinin ortaya koydukları içerik analizi çalışmaları -özelde arşivcilik konularını kapsamlı bir şekilde yansıtmasa da-kısmen yansıtmaktadır. Bu anlayışı benimseyip arşivcilikle ilgili yazıların içerik analizi değerlendirmesini yapan herhangi bir çalışma Türkiye'de henüz bulunmamaktadır. Mesleğin gelişme gösterdiği ülkelerdeki çalışmalara bakıldığında, arşivcilik disiplinin temel konularını belirlemeye yönelik yüksek lisans tezleri yapıldığı görülmektedir. Bu tezlerde, farklı ülkelerde bibliyometri konusunu ilgilendiren arşivcilikle ilgili yazıların yayınlandığg, Türkiye'deki Arşiv Dünyası dergisi bağlamında değerlendirilebilecek kimi dergilerin içerik analizinin yapılmış olduğu anlaşılmaktadır. Bu çalışmalardan Writney E. Berman'ın yüksek lisans tezinde American Archivist dergisinin arşivcilik literatürü açısından analizi yapılmaktadır. Wakefield Harper'ın yüksek lisans tezinde ise dünyadaki arşivcilik alanıyla ilgili beş önemli derginin içerik analizi yapılmaktadır. Bu dergiler; American Archivist, Archivaria, Archives and Manuscripts, Journal of the Society of Archivists ve Archival Science’tır. Bu dergilerde 30 yıl boyunca yayınlanmış olan yazıların değerlendirilmesi ve arşivcilik alanındaki konuların belirlenmesi bu çalışma açısından da önemlidir. Bu çalışmalara göre belirlenen makale konuları ise 11 başlık altında toplanmıştır (Tablo 2). Arşiv Dünyası dergisinde yayınlanan makale konuları da söz konusu yüksek lisans tezinde belirlenen konu başlıkları çerçevesinde ele alınmıştır. Bunlar haricindeki konular ise "diğer" şeklinde başlıklandırılmıştır.

Tablo 3: Makale konularının listesi

\begin{tabular}{|l|l|}
\hline 1. Education in archival studies & 1. Arşivcilik eğitimi \\
\hline 2. Archival appraisal & 2. Arşivsel değerlendirme \\
\hline $\begin{array}{l}\text { 3. Archival arrangement/description (includes } \\
\text { discussion of processing and provenance) }\end{array}$ & $\begin{array}{l}\text { 3. Arşivsel düzenleme/tanımlama (provenans ve } \\
\text { arşivsel süreçlerin tartış1lması ile ilgili yazılar dâhil) }\end{array}$ \\
\hline $\begin{array}{l}\text { 4. Archival access (user services, instruction, public } \\
\text { displays) }\end{array}$ & $\begin{array}{l}\text { 4. Arşivsel erişim (kullanıcı hizmetleri, talimatlar, } \\
\text { arşivsel tanıtım) }\end{array}$ \\
\hline $\begin{array}{l}\text { 5. Administration/planning/management } \\
\text { 6. Special archival environments and collections (for } \\
\text { instance, archives in a particular country or context) }\end{array}$ & $\begin{array}{l}\text { 6. Özel arşivler ve koleksiyonları (örneğin, belirli bir } \\
\text { ülkedeki veya konudaki arşivler) }\end{array}$ \\
\hline $\begin{array}{l}\text { 7. Special archival formats (such as digitally-born } \\
\text { materials, microfilm, photographs) }\end{array}$ & $\begin{array}{l}\text { 7. Farklı arşivleme formatları (dijital doğan } \\
\text { malzemeler, mikrofilm, fotoğraflar gibi) }\end{array}$ \\
\hline $\begin{array}{l}\text { 8. Archival ethics, political and legal issues } \\
\text { 9. Preservation/conservation }\end{array}$ & 8. Arşivsel etik, siyasi ve yasal konular \\
\hline $\begin{array}{l}\text { 10. Professional issues (for instance, surveys on the } \\
\text { archival profession, reflections onthe archivist's role, } \\
\text { etc.) }\end{array}$ & $\begin{array}{l}\text { 10. Mesleki konular (örneğin, arşiv mesleği üzerine } \\
\text { yaplan araştırmalar, arşivcinin rolü, vb.) }\end{array}$ \\
\hline \begin{tabular}{l} 
11. Biography \\
\hline
\end{tabular} & 11. Biyografi \\
\hline
\end{tabular}


Arşiv Dünyası dergisindeki hakemli ve hakemsiz 169 yazının konuları bu tablodaki listeye göre sıralandığında; arşivsel değerlendirme (\%1,18), arşivsel düzenleme/tanımlama $(\% 4,73)$, arşivsel erişim $(\% 2,37)$, arşivsel etik, siyasi ve yasal konular $(\% 8,28)$, biyografi $(\% 2,37)$, diğerarşivcilikle ilgisi olmayan konular- $(\% 52,07)$, farklı arşivleme formatları $(\% 4,73)$, mesleki konular $(\% 10,65)$, özel arşivlerve koleksiyonları $(\% 13,02)$, saklama/koruma $(\% 0,59)$ şeklinde bir konu dağılımı karşımıza çıkmaktadır. Buna ilişkin bir tablo şu şekildedir:

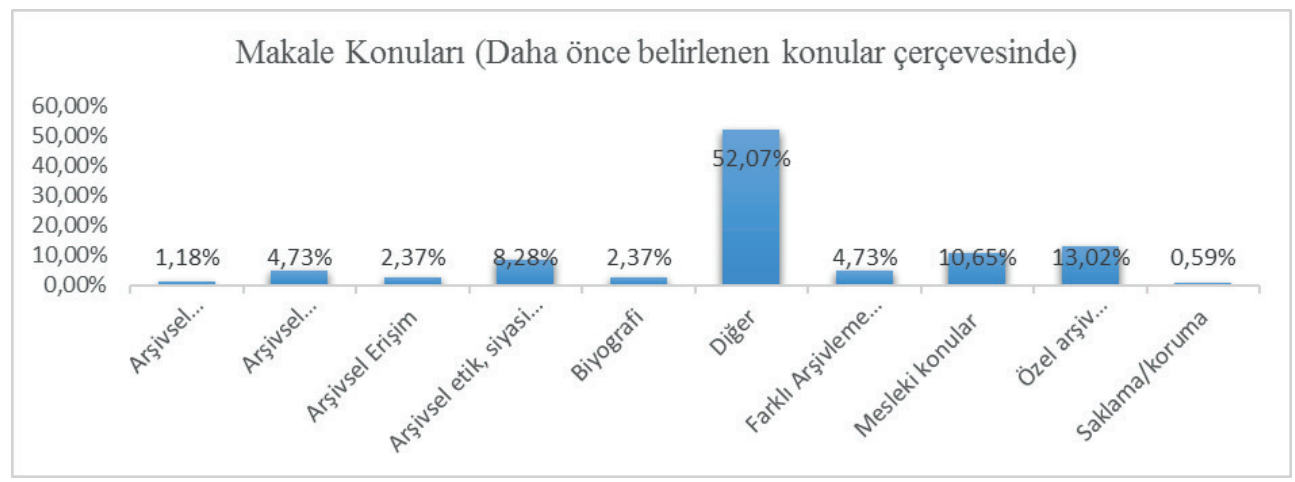

Şekil 2: Makale konuları

\section{Makalelerde Kullanılan Araştırma Yöntemi ve Veri Toplama Teknikleri}

Araştırmalarda yararlanılan bilimsel yöntemlerin önemi büyüktür; çünkü yöntem, çalışmalarda problemlerin nasıl bir yaklaşımla ele alınması gerektiğini yansıtan önemli bir göstergedir. Bu gösterge çalışma sonuçlarının uygulanmasında araştırmacıya yardımcı olmaktadır (Özenç-Uçak, 2008, s. 38). Arşiv Dünyası dergisinde yayınlanan yazılara ait yöntemler değerlendirildiğinde, ele alınan makalelerin çoğunda bilimsel yöntemin yazar tarafından belirtilmediği dikkat çekmektedir. Yöntemi yazar tarafından belirtilen çalışmalar, metinde belirtildiği şekilde değerlendirilmiştir. Yöntemini belirtmeyen yazarların yazıları, Jarvelin ve Vakkari'nin kullandığı yöntem listesine göre, yazıların öz veya giriş kısımları taranarak listedeki başlıklar çerçervesinde incelenmiştir. Değerlendirilen 169 hakemli ve hakemsiz makalede, -makale metni içinde hiçbir şekilde belirtilmemesine rağmen- $\% 42,60$ oranında betimsel yöntem kullanıldığı tespit edilmiştir. Betimleme yöntemi kullanan ve çalışmasında bunu belirtenlerin oranı ise \%1,18' dir. İçerik analizi yöntemi ve tarihsel yöntem (makale metninde belirtilmemiş olanlar) kullanılan yazıların oranı eşit olup \%17,75’tir. Yine makale metninde belirtilmemiş olup örnek olay araştırması yöntemini kullananların oranı ise \%7,69'dur. Öne çıkan diğer değerler ise \%2,69 ile kavram analizi yöntemidir (makale metninde belirtilmemiştir). Bir diğer oran ise \%2,37 ile makale metninde belirtilmeyen tartışma yöntemidir. 


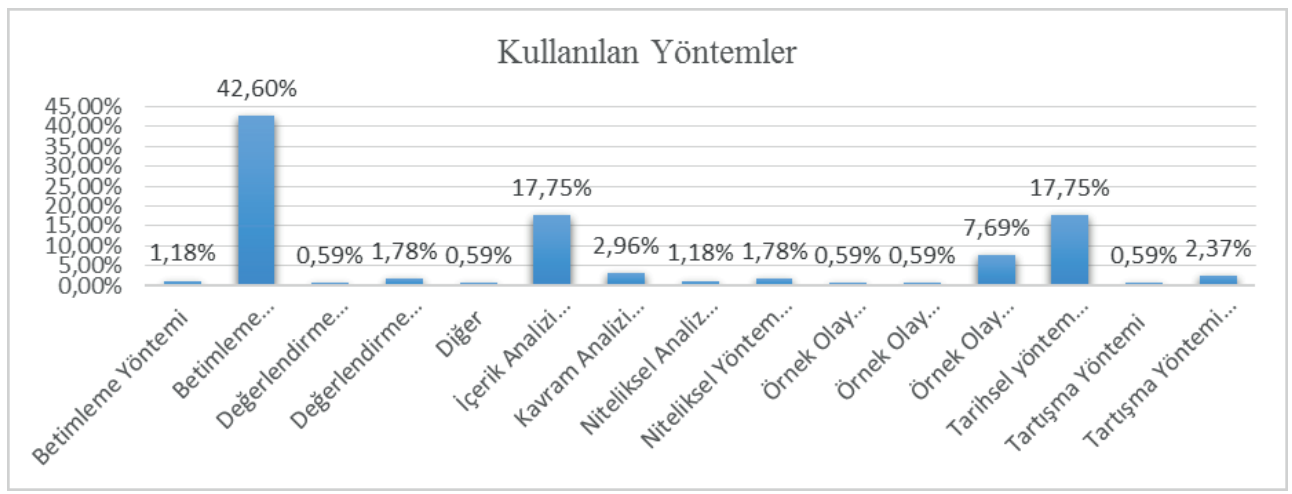

Şekil 3: Makalelerde kullanılan yöntemler

Makalelerin veri toplama teknikleri,-yöntem kısmında olduğu gibi- Jarvelin ve Vakkari’nin kullandığ 1 veri toplama teknikleri listesine göre değerlendirilmiştir. Veri toplama teknikleri kullandığı tekniği belirtenler ve belirtmeyenler olmak üzere iki şekilde ele alınmıştır. Kullandığı tekniği belirtenlerin tamamı derginin hakemli olduğu sayılardaki yazılardır. Hakemli olup hiçbir şekilde tekniği belirtmeyenler de bulunmaktadır. \%33,73 oranında (belirtilmeyen) birkaç veri toplama tekniği kullanılmıştır. Yine (belirtilmeyen) \%25,44 oranında tarihsel kaynak analizi tekniği kullanılmıştır. İçerik analizi tekniğini kullananların (belirtilmeyen) oranı ise \%20,71'dir. Diğer öne çıkan oranlar ise, \%8,88 ile gözlem tekniği, \%4,73 ile yüksek sesle düşünme tekniğidir. Kullanılan tekniğin makale metninde belirtildiği yazıların oranı ise şöyledir: Aynı yazıda birden fazla kullanılan veri toplama tekniği \%3,55, tarihsel kaynak analizi \%1,78, gözlem $\% 0,59$.

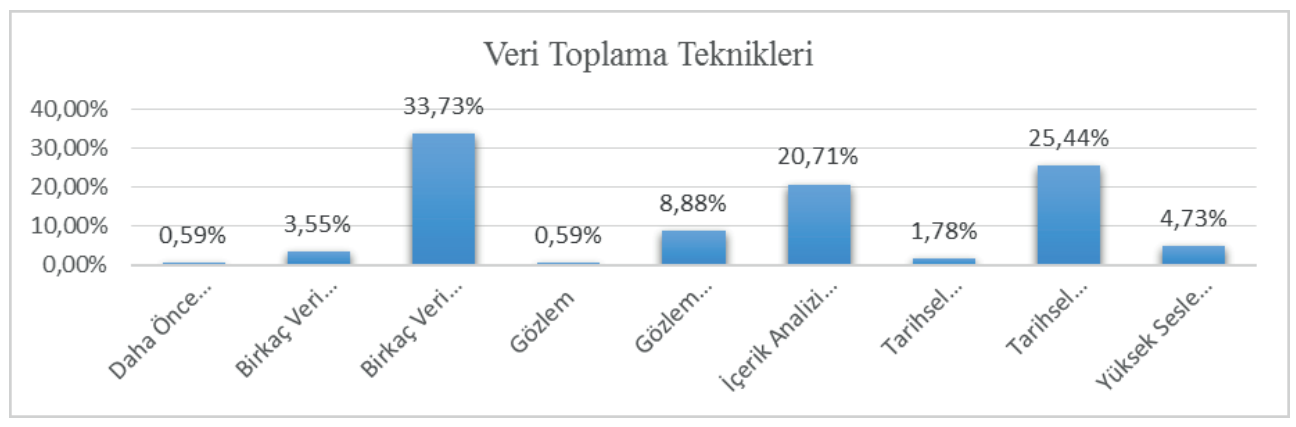

Şekil 4: Makalelerde kullanılan veri toplama teknikleri 


\section{Makalelerdeki Türkçe-İngilizce $\ddot{O}_{z}$ Durumu}

Çalışmalardaki Türkçe-İngilizce öz durumunu değerlendirdiğimizde, \%85,80 (145 adet) oranındaki yazılarda Türkçe ve İngilizce öz bulunmamaktadır. Bu durum, yazıların sadece \%14,20 (24 adet) kadarında Türkçe-İngilizce öz veya sadece Türkçe öz bulunduğunu göstermektedir. Buna göre hem Türkçe hem de İngilizce öz bulunan yazıların kendi içerisindeki oranı \%13,02'dir (22 adet). Sadece Türkçe öze sahip yazıların oranı da \%1,18'dir (2 adet). Sadece İngilizce öze sahip makale ise bulunmamaktadır. Arşiv Dünyası dergisine yazı gönderen yazarların büyük oranda öz hazırlamadıkları görülmektedir. Derginin yayın ilkelerinde geçen "Yazım Kuralları, Madde 3'te"“"Makalenin başında konuyu kısa ve öz biçimde anlatan ve en az 100, en çok 200 kelimeden oluşan Türkçe ve İngilizce özet bulunmalıdır” (Türk Arşivciler Derneği, 2013, s. 90) ilkesi açık şekilde ve genel olarak göz ardı edilmiştir. Yazıların bu kurallara uygunluğunu değerlendirecek olanlar kuşkusuz editörlerdir. Editörlerin yazıları yayın ilkelerine göre değerlendirmediği anlaşılmaktadır. Dergilerin kalite göstergelerinden olan öz bulundurma, bazı kurumların -hangi dergileri listelerine eklemeleri gerektiği noktasında tek bir ölçüt olmasa da- şart koştuğu temel ölçütler arasında yer almaktadır. Örneğin, Institute of Scientific Information (ISI, Toronto-Kanada) listesine alacağı dergilerde makalelerin İngilizce öz veya özetlerini şart koşmaktadır (Kozak, 2003, s. 153).

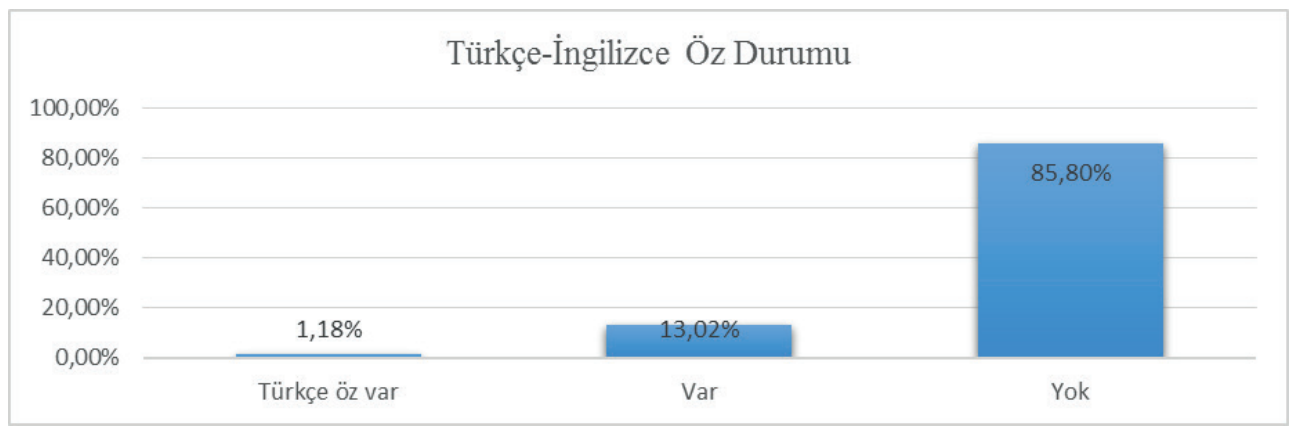

Şekil 5: Makalelerdeki Türkçe-İngilizce öz durumu

\section{Makalelerdeki Dipnot-Kaynakça Durumu}

Bu başlıkta dergi içerisinde yayınlanan makalelerde dipnotun ve kaynakçanın yer alması konusu değerlendirilmiştir. Aşağıdaki grafikte buna dair veri bulunmaktadır. Tablo 6' da" "Var" olarak belirtilen sütunda hem dipnotun hem de kaynakçanın olduğu gösterilmek istenmiştir."Yok" şeklinde belirtilen sütunda ise dipnot ve kaynakçanın her ikisinin de olmadığı ifade edilmektedir. Yazıların \%34,91'inde dipnot kullanılmıştır. \%15,98 oranında ise yazılarda kaynakça bulunmaktadır. Dipnotun ve kaynakçanın hiçbir şekilde olmadığı yazıların oranı \%31,36'dır. Bunların bir kısmı, kuşkusuz serbest/deneme tarzında yazılan yazılardan oluşmaktadır. Dipnot 
ve kaynakçanın her ikisinin de olduğu yazıların oranı \%17,75’tir. Arşiv Dünyası dergisinin yayın ilkelerine baktığımızda 8. maddede kaynak gösterme ve atıflar, 9. maddede kaynakçanın olması gerektiği vurgusu olmasına rağmen (Arşiv Dünyası Dergisi, 2013, s. 91-92) bu ilkelere büyük oranda uyulmadığı anlaşılmaktadır.

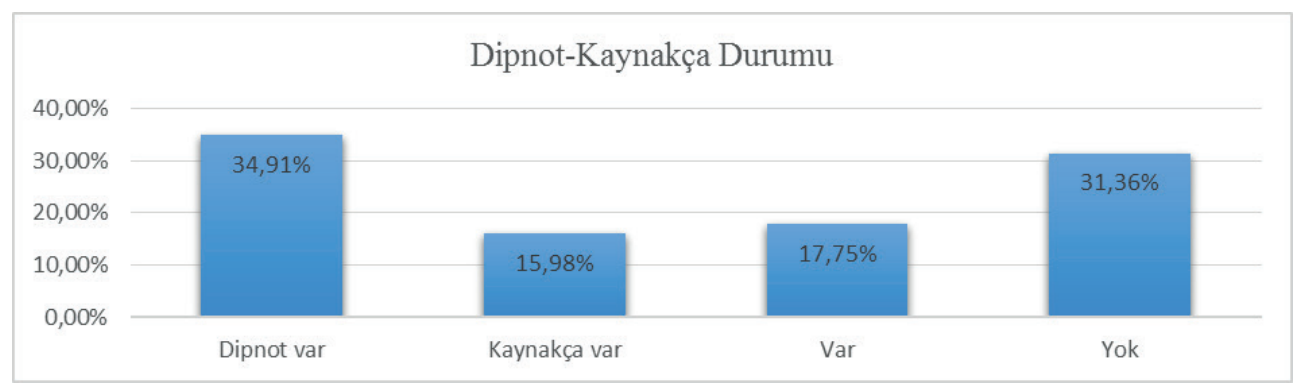

Şekil 6: Makalelerdeki dipnot-kaynakça durumu

\section{Yazarların Çalıştığı Kurum}

Makale yazarlarının \%33,73 oranında Başbakanlık Devlet Arşivleri Genel Müdürlüğü (artık Devlet Arşivleri Başkanlığı) çalışanları olarak katkı sağladıkları görülmektedir. Kurumu belirtilmeyen yazar oranı ise \%18,93'dür. Bunlar haricinde yazarlarıyla öne çıkan kurumlar, \%9,47 oranında katkı ile İstanbul Üniversitesi Bilgi ve Belge Yönetimi Bölümü, \%5,92 oranında katkı ile Marmara Üniversitesi Bilgi ve Belge Yönetimi Bölümü, \%3,55 oranında katkı ile Atatürk Üniversitesi Bilgi ve Belge Yönetimi Bölümü, \%1,18 oranında katkı ile Ankara Üniversitesi Bilgi ve Belge Yönetimi Bölümüdür. Diğer Bilgi ve Belge Yönetimi Bölümlerindeki öğretim üyelerinin dergide herhangi bir katkıda bulunmadıkları dikkat çekicidir. Sonuçları değerlendirdiğimizde, meslek çalışanlarının Arşiv Dünyası dergisine büyük oranda katkı sağladığı görülmektedir.

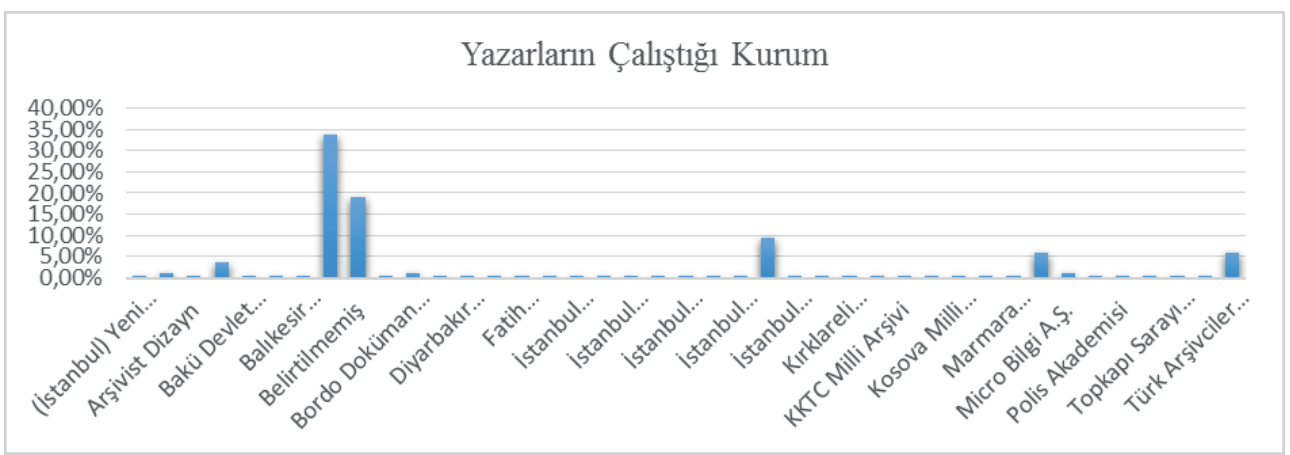

Şekil 7: Yazarların hangi kurumlardan katkıda bulundukları 


\section{SONUÇ VE DEĞERLENDİRME}

Betimsel bibliyometri olarak ifade edilen içerik analizi çalışmaları Türkiye'de 1980'li yıllardan itibaren araştırma konusu olmaya başlamıştır. Bu çalışmalar incelendiğinde, genellikle kütüphanecilik alanındaki dergiler ve tezler için değerlendirmeler yapıldığı dikkat çekmektedir. Buna karşın, arşivcilikle ilgili yapılan yayınların veya bir arşivcilik dergisinin bibliyometri merkezli çalışmalara konu edilmesi henüz gerçekleşmemiştir. Türk Arşivciler Derneği tarafindan 1999 yılından beri yayınlanan Arşiv Dünyası dergisinin bibliyometri eksenli bir çalışmaya konu edilmesi bu bakımdan bir ilki oluşturmaktadır. İstenilen şekilde (yılda 2 defa) yayın hayatına devam edememesi, yayınlanan sayılarda da içerik olarak problemler olması söz konusu derginin arşivcilik alanına yönelik fonksiyonları yeterince yerine getiremediği ve beklenen mesleki faydayı sağlayamadığı şeklinde yorumlanabilir. Bu durum, Arşiv Dünyası dergisinin mevcut halinin analiz edilmesini ayrıca gerekli kılmıştır. Ortaya çıkan sonuçların, sorumluların daha nitelikli bir yayın faaliyetinin başlatılması yönünde güçlü bir karar almalarında belirleyici olabileceği düşünülmektedir.

Arşiv Dünyası dergisi için yapılan içerik analizi, yayın türü, sayfa sayıları, makale konuları, makalelerde kullanılan yöntem, veri toplama tekniği, makalelerdeki Türkçe-İngilizce öz durumu, dipnot-kaynakça bilgisi ve yazarların hangi kurumlardan katkıda bulundukları bilgisi şeklinde değerlendirilmiştir. Söz konusu dergide yayınlanan hakemsiz makalelerin oranı \%32,99, hakemli makalelerin oranı ise \%24,49'dur. \%57,48 oranında mesleki ve (başka alanları da içeren) bilimsel makalelere yer verilmesi, arşivcilik alanıyla ilgili problemlerin ve gelişmelerin dergide belirgin bir yere sahip olduğunun göstergesidir. Yayın türlerinde dikkat çekici bir değer olan kitap tanıtımlarının \%12,24 oranında kendisine yer bulmuş olması anlamlıdır. Bu durum, ilk bakışta olumlu bir tablo ortaya koysa da, tanıtımı yapılan kitapların çoğunun arşivcilikle ilgili olmaması düşündürücüdür. Bu durumun derginin mesleki camiada yer bulacak imajına zarar verdiği açıktır. Hâlbuki, arşivcilik alanındaki dergilerin, -mesleki bakımdan gelişme göstermiş ülkelerde olduğu gibi`- sadece mesleki alanla ve mesleğin interdisipliner özelliğini yansıtır şekilde bir yayın tanıtım politikasının belirlenmesi gerekirdi.

Toplam sayfa sayıs1 1.189 olan 17 sayının $636(\% 53,49)$ sayfası derginin hakemli olmadığı yıllardaki sayfa sayısıdır (1-10 arası sayıların toplam sayfa sayısı). Hakemli olduktan sonra da toplam 553 sayfa $(\% 46,50)(11-17$ arası sayıların toplam sayfa sayısı) yayınlanmıştır. Toplam sayfa sayısının dergi sayılarına göre ortalaması 69,94'tür. Derginin bütün yayın türlerine (294) göre sayfa ortalamasına baktığımızda ise, her yayının ortalama sayfa adedi 4,04'tür. Derginin sayfa sayıları, derginin sayılarına göre normal düzeydedir; fakat mesleki ve bilimsel makalelere ağırlık verilip, gerekli olmayan bazı konuların dergi içeriğinden çıkartılması, derginin toplam

7 Arşivcilik alanında önemli bir dergi olan The American Archivist dergisinin kitap tanıtım bölümlerine bakılabilir (Çevrimiçi: http://americanarchivist.org/action/doSearch?AllField=book+review). 
sayfa sayısının mesleki ve bilimsel makalelere ayrılması mümkün olabilseydi, derginin yayın kalitesinin daha güçlü olması sağlanabilirdi.

Dergide yayınlaran makalelerde ele alınan konuların \%52,07'si arşiv ve arşivcilikle ilgili değildir. Makalelerin \% 47,93'ü ise arşiv ve arşivcilikle ilgili konulardan oluşmaktadır. Wakefield Harper'ın tezindeki 11 başlığa göre konularına ayrılan Arşiv Dünyası dergisinde yayınlanan mesleki (hakemsiz) ve hakemli makalelerin Harper'ın belirlediği konularla büyük oranda uyum sağladığı görülmektedir. Arşiv Dünyası dergisinde ele alınmayan tek konu ise yönetim/ planlama/yürütmedir. -Önemli ve çalışılması gereken bir konu olmakla birlikte- bu konunun Türkiye'de araştırmaya veya tartışmaya konu olmaması düşündürücüdür. \%52,07 oranında arşivcilikle ilgili olmayan yayınların dergi içeriğinde yer bulması, Arşiv Dünyası dergisinin yayın politikasında bir sorun olduğunu ortaya koyan önemli bir bulgudur. Özel arşiv ortamları ve koleksiyonları ile ilgili konulara \%13,02 oranında, mesleki konulara \%10,65 oranında yer verilmesi Arşiv Dünyası dergisinin profilini belirleyen diğer önemli bulgulardır. Bir diğer önemli bulgu ise arşivsel etik, siyasi ve yasal konulardır. Bu konuların oranı ise \%8,28' dir. Bu durum Türkiye'de arşivcilik alanında hukuki sorunların olduğunu ve bu sorunların mesleki ve bilimsel makalelerde ifade edilmeye çalışıldığını, bu yolla mesleki kamuoyunu bilgilendirme ve kamuoyu oluşturma çabalarının yoğunluğuna işaret etmektedir.

Kullanılan yöntemlere baktığımızda, \%33,19 oranında betimleme yöntemi ve \%27,73 oranında ise içerik analizi yönteminin öne çıktığı görülmektedir. Arşiv Dünyası dergisinde kullanılan yöntemler sırasıyla betimleme, içerik analizi, tarihsel yöntem, örnek olay araştırması, kavram analizi ve tartışma yöntemi olmak üzere 6 farklı yöntem üzerinde yoğunlaşmaktadır. Bununla birlikte makalelerde çalışma yönteminin belirtilmemesi dergi için genel bir durumdur. Bu durum, söz konusu derginin 2008 yılından itibaren hakemli olarak yayınlanmasından sonra da genel olarak bu şekilde devam etmiştir. Yayınlanan hakemli makalelerin birçoğunda yöntemin makale metninde belirtilmemiş olması, Arşiv Dünyası dergisinin yazarlardan bunu istememesi/yazarların zorunlu tutulmaması ile açıklanabilir. Mevcut duruma göre, yazarların bir kısmı çalışmada kullanılan yöntemi açıkça ifade etmeyi bir kısmı da tam aksine bir eğilim ortaya koymayı tercih ettikleri açıktır. Günümüz Web of Science (WOS) gibi bilimsel dergi yayıncılığında yazarlar tarafından çalışmanın yönteminin açıkça ifade edilmesi yaygın bir kuraldir.

Veri toplama tekniğinde ise $\% 29,83$ oranında içerik analizi ve $\% 24,79$ oranında ise birkaç veri toplama tekniği kullanılmıştır. Kullanılan veri toplama teknikleri, yazarların çoğunluğunda metin içinde belirtilmemiştir. Veri toplama tekniğini belirtenlerin ise üniversitedeki öğretim üyelerinin çalışmalarında yoğunlaştığı görülmektedir.

Türkçe-İngilizce öz durumunu değerlendirdiğimizde, \%85,71 oranında Türkçe-İngilizce öz bulunmadığı, \%11,64 oranında hem Türkçe hem de İngilizce öz bulunduğu, \%2,65 oranında 
ise sadece Türkçe öz bulunduğu görülmektedir. Çalışmalarda; \%35,11 oranında dipnot ve kaynakça verilmemiştir; \%31,91 oranında sadece dipnot verilmiştir; \%17,08 oranında sadece kaynakça verilmiştir; \%15,96 oranında ise hem dipnot hem de kaynakça verilmiştir. Arşiv Dünyası dergisinin yayın ilkelerinde kaynak gösterme ve atıf kurallarının nasıl olması gerektiği vurgulanırken, yazarların kaynak ve atıf göstermede bu kuralları uygulamadıkları görülmektedir. Muhtemelen editörler, dergiye yazı bulma endişelerinden dolayı yazarları zorlamamışlar, bu nedenle kaynak ve atıf gösterme kuralları göz ardı edilmiştir. Bu uygulamanın her ne kadar iyi niyetle yapılmış bir uygulama olduğu düşünülebilirse de, gelinen noktanın dergi imajına ve bilimsel saygınlığına zarar verdiği âşikardır. Bu sebeple,-dergiye yazı bulamama pahasına da olsa- derginin daha nitelikli ve alanında söz sahibi olabilmesi için,bilimsel araştırma ilkelerinin yayınlarda uygulanması önemli bir konudur. Yayın ilkeleri güçlü bir derginin mesleki camiada ve bilimsel yayıncılık alanında saygınlığının artmasını sağlayacağı ve bu durumun da yayın taleplerini sayıca artıracağı açıktır.

Makalelerdeki yöntem, veri toplama tekniği, Türkçe-İngilizce öz bulundurma ve dipnotkaynakçanın göz ardı edilmesi ve bunun genellikle meslek çalışanlarınca yapıldığı, çalışmanın analiz sürecinde açık bir şekilde gözlemlenebilmiş bir konudur. Belirlenen bu durum, uygulamada yer alan ve özellikle de Devlet Arşivleri Başkanlığı çalışanlarından gelen yüksek katkının dergi niteliklerinin ve yayın zorunluluklarının dikkate alınmadığı anlamını taşır niteliktedir. Öğretim üyelerinin bir kısmının da aynı şekilde belirtilen ilkeleri dikkate almadığı görülmektedir. Söz konusu ilkelerin uygulanmasında açıkça sorumluluk sahibi olan editörlerin, kendilerine havale edilen yükümlülükleri gereği gibi yerine getirmedikleri anlaşılmaktadır.

Son olarak araştırmacıların kurumlarını değerlendirdiğimizde, makalelerin yazarları büyük bir oranda tek yazarlı olup yurt içi ve yurt dışından 33 farklı kurumdan 108 farklı araştırmacının katkısı bulunmaktadır. Üniversitelerin Bilgi ve Belge Yönetimi Bölümlerinden katkı sağlayan öğretim üyelerinin yazılarını alanında tek olan Arşiv Dünyası dergisinde yayımlamayı tercih etmiş olmaları, derginin önemsendiğini göstermektedir. Derginin ulusal ve uluslararası indekslerde taranmasının gerçekleşmesi halinde, derginin mesleki camiada daha fazla önemseneceğine ve talep göreceğine kuşku yoktur.

Hakem Değerlendirmesi: Dış bağımsız.

Çıkar Çatışması: Yazarlar çıkar çatışması bildirmemiştir.

Finansal Destek: Yazarlar bu çalışma için finansal destek almadığını beyan etmiştir.

Peer-review: Externally peer-reviewed.

Conflict of Interest: The authors have no conflict of interest to declare.

Grant Support: The authors declared that this study has received no financial support. 


\section{Kaynakça/References}

Abu Isneineh, S. (1996). Türkiye ve Ürdün'de yayımlanan kütüphanecilik dergilerinin karşılaştırmalı içerik analizi (Yayımlanmamış yüksek lisans tezi). Hacettepe Üniversitesi Sosyal Bilimler Enstitüsü, Ankara.

Allen, B. ve Reser, D. (1990). Content analysis in library and information science research. LISR, 12(3), 251-261.

Altınörs, G. (1983). Türkiye'de kütüphanecilik bilim dalı konusunda yapılmış olan doçentlik, doktora ve bilim uzmanlığı tezlerinde kullanılmış araştırma metodları (Yayımlanmamış bilim uzmanlığı tezi). Hacettepe Üniversitesi, Ankara. Erişim adresi: http://www.bby.hacettepe.edu.tr/yayinlar/dosyalar/7.pdf

Atkins, S. E. (1988). Subject trends in library and information science research. Library Trends, 36(3), 633-658.

Auld, L. W. S. (1988). Library Trends past and present: A descriptive study. Library Trends, 36(4), 853-868.

Berman, W. E. (2004). Archival literature: Analysis of the evolution of American Archivist (Unpublished master thesis). University of North Carolina at Chapel Hill. Erişim adresi: https://cdr.lib.unc.edu/indexablecontent/ uuid:760558bc-bd53-4f83-81f8-5e2636fa6d20

British Standards Institution. (1976). Glossary of documentation terms. Published under the authority of the Executive Board, prepared under the direction of the Documentation Standards Committee.

Busha, C. H. ve Harter, S. P. (1980). Research methods in librarianship: Techniques and interpretation. New York: Academic Press.

Campbell, F. (1896). The theory of national and international bibliography. London: Library Burea. Erişim adresi: https://ia802706.us.archive.org/25/items/theorynationala00campgoog/theorynationala00campgoog.pdf

Carrizo-Sainero, G. (2000). Toward a concept of bibliometrics. Journal of Spanish Research on Information Science, 1(2), 1-6.

Chin Roemer, R. ve Borchardt, R. (2015). Meaningful metrics: A 21 st century librarian's guide to bibliometrics, altmetrics, and research impact. Chicago: Association of College and Research Libraries.

Cole F.J. ve Eales N.B. (1917). The history of comparative anatomy: Part 1: A statistical analysis of the literature. Science Progress, 11, 578-596.

Cooper, W. D. (1987). Library literature in mainland China: A content analysis. College and Research Libraries, 48(5), 194-202.

Çakın, Y. (1980). Türk Kütüphaneciler Derneği Bülteni'nin içerik ve yazar yönünden değerlendirilmesi (Yayımlanmamış bilim uzmanlığı tezi). Hacettepe Üniversitesi, Ankara. Erişim adresi: http://www.bby. hacettepe.edu.tr/yayinlar/dosyalar/68.pdf

Dernekler Yönetmeliği. (2005, 31 Mart). Resmi Gazete (Sayı: 25772). Erişim adresi: http://www.resmigazete. gov.tr/eskiler/2005/03/20050331.htm

Devlet Arşivleri Başkanlığı Hakkında Cumhurbaşkanlığı Kararnamesi. (2018, 16 Temmuz). Resmi Gazete (Sayı: 30480, Kararname Say1: 11). Erişim adresi: http://www.resmigazete.gov.tr/eskiler/2018/07/20180716-1.pdf

Garfield, E. (1973). Historiographs, librarianship and the history of science. In C. H. Rawski (Ed.), Toward a theory of librarianship: Papers in honor of Jesse Hauk Shera (s. 380-402). Metuchen, NJ: Scarecrow Press.

Harper, W. (2010). A content analysis of archival journal literatüre (Unpublished master thesis). University of North Carolina at Chapel Hill. Erişim adresi: https://cdr.lib.unc.edu/indexablecontent/uuid:db68dd19c04b-4bad-9d9f-d7969ffc5c36

Holmberg, K. (2016). Altmetrics for information professionals: Past, present and future. Kidlington: Chandos Publishing, Elsevier. 
Hood, W. W. ve Wilson, C. S. (2001). The literature of bibliometrics, scientometrics, and informetrics. Scientometrics, 52(2), 291-314. Erişim adresi: http://www.master-vti.fr/web/IMG/pdf/The_Literature_ of_Bibliometrics_Scientometrics_and_Informetrics-2.pdf

Hulme E. W. (1923). Statistical bibliography in relation to the growth of modern civilization. London: Grafton.

Jarvelin, K. ve Vakkari, P. (1990). Content analysis of research articles in library and information Science. Library and Information Science Research, 12, 395-421.

Jarvelin, K. ve Vakkari, P. (1993). The evolution of library and information science 1965-1985: A content analysis of journal articles. Information Processing and Management, 29, 129-144.

Karagözlü-Asliyüksek, M. (2016). Bilgi teknolojileri ve dijitalleşmenin Türkiye'de bilgi bilim literatürüne yansıması: Bilgi Dünyası Dergisi örneği (2000-2014). Bilgi Dünyası, 17(1), 87-103.

Kozak, N. (2003). Türkiye'de yayınlanan akademik dergilerin niteliklerindeki zaman içerisindeki değişim nedenleri: Sağlık, sosyal ve teknik bilim alanlarında yayınlanan dergiler üzerine bir inceleme. Bilgi Dünyasl, 4(2), 146-174.

Kumpulainen, S. (1991). Library and information science research in 1975: Content analysis of the journal articles. Libri, 41, 59-76.

Nicholas, D. ve Ritchie, M. (1978). Literature and bibliometrics. London: Clive Bingley.

Osareh, F. (1996). Bibliometrics, citation analysis and co-citation analysis: A review of literature I. Libri, 46, 149-158. Erişim adresi: https://www.degruyter.com/downloadpdf/j/libr.1996.46.issue3/libr.1996.46.3.149/ libr.1996.46.3.149.pdf

Özenç-Uçak, N. (2008). Kütüphanecilik ve bilgi yönetimi literatüründe kullanıcı. Bilgi Dünyası, 9(1), 20-40.

Rochester, M. K. (2016). Library and information science research in Australia 1985-1994: A content analysis of research articles in the Australian Library Journal and Australian Academic and Research Libraries. Australian Academic and Research Libraries, 47(4), 207-214.

Sengupta, I. N. (1992). Bibliometrics, informetrics, scientometrics and librametrics: An overview. Libri, 42(2), 75-98. Erişim adresi: https://tr.scribd.com/document/157582177/Sengupta-Bibliometrics-InformetricsScientometrics-and-Librametrics-An-Overview

Snelson, P. ve Talar, S. A. (1991). Content analysis of ACRL conference papers. College and Research Libraries, 52(2), 467-472.

Şahin, H. H. (2006). Derneğimiz 'Türk Arşivciler Derneği' adını aldı, misyonumuz ve vizyonumuz. Arşiv Dünyası, 9, 3-4.

T.C. Cumhurbaşkanlığı Devlet Arşivleri Başkanlığı (2019). Hakkımızda. Erişim adresi: https://www. devletarsivleri.gov.tr/Sayfalar/Sayfa/9/ADA45D7B737CBC58F13C672C0AECCA8E9F0DDB54A7AB 8426349949A5FDEB9E15

Tonta, Y. (2002). Türk Kütüphaneciliği dergisi, 1987-2001. Türk Kütüphaneciliği, 16(3), 282-320.

Türk Arşivciler Derneği. (2013). Arşiv Dünyası Dergisi’nin yayın ilkeleleri. Arşiv Dünyası, 14-15.

Türk Arşivciler Derneği. (2017). Hakkımızda. Erişim adresi: http://www.arsivder.org.tr/.

Türk Arşivciler Derneği. (2017). Misyon ve vizyon. Erişim adresi: http://www.arsivder.org.tr/.

Walia, P. K. ve Manpreet, K. (2012). Content analysis of journal literature published from UK and USA. Library Philosophy and Practice, 833, 1-17.

Yavuz, F. (1999). Editör'den. Arşiv Dünyası Bülteni, 1. 
Yılmaz, M. (1999). Kütüphane ve bilgibilim açısından bibliyometrinin önemi (Yayımlanmamış yüksek lisans tezi). İstanbul Üniversitesi Sosyal Bilimler Enstitüsü, İstanbul.

Yontar, A. (1995). Main research problems being investigated in Turkey as revealed in graduate theses. Booklet 7, Division of Education and Research, 61st IFLA Council and General Conference, Istanbul, Turkey, August 20-26, 1995 içinde (s. 38-47). İstanbul: IFLA.

Yontar, A. (1998). Türkiye'de kütüphane ve bilgi bilimi konusundaki başlıca araştırma sorunlarının lisansüstü tezlerinde yansıması. Kütüphanecilik Dergisi: Belge Bilgi Kütüphane Araştırmaları, 4(1), 1-17.

Yontar, A. ve Yalvaç, M. (2000). Türkiye'de kütüphane ve bilgi bilimi konusundaki araştırma sorunları: 1952-1994 yıllarında yayınlanan dergi makalelerinin içerik analizi. Kütüphanecilik Dergisi: Belge Bilgi Kütüphane Araştırmaları, 6(1), 165-186. 
